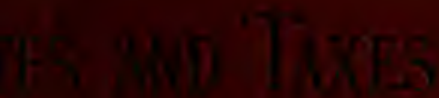

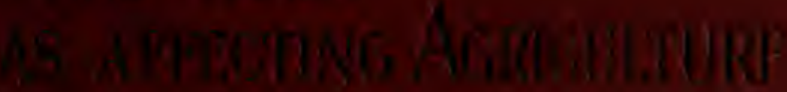

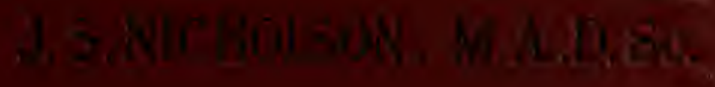




Digitized by the Internet Archive in 2007 with funding from Microsoft Corporation 
RATES AND TAXES

AS AFFECTING AGRICULTURE 


\section{THE HISTORY OF THE ENGLISH CORN LAWS}

By J. S. NICHOLSON, M.A., D.Se.,

Professor of Political Economy in the University of Edinburgh. Author of "Effects of Mackinery on Wages," \&c.

Cloth, 2s. 6d.

[Soc. Sc. Series.

\section{OPINIONS OF THE PRESS.}

"The learned Professor gives a clear and succinct account of the history of the English Corn Laws. He treats them very ably from three standpoints as affecting the consumer, the producer, and national interests. In the chapter devoted to general results, he asserts that the history of the Corn Laws strongly supports the negative argument for Free Trade." Dundee Courier.

"Based on a set of lectures delivered at Cambridge last year, the book examines the working of the Corn Laws in connection with the general economic policy of the country, and after a close scrutiny, in the light of Adam Smith's reasoning, of the actual results of the duties and restrictions upon imports, finds that they either failed of their objects or were actively hurtful. The work should prove welcome to many readers at this time, both within and without the circle of professed students of economic history."-Scotsman.

"The principal object of this work is to show that the history of the Corn Laws can only be understood as part of the general economic policy of the country." -Outlook.

"The subject is dealt with in four chapters, devoted respectively to the points of view of the consumer, producers, and public policy, and to general results. From the fact that the old Corn Laws were part of a system, and were destroyed with that system, it is argued that by analogy a new or revised Corn Law can also only be part of a general system, whether of Protection or Preference."-Nolls Guardian.

"Professor Nicholson, by reprinting the four lectures on Corn Law history that he delivered at Cambridge University last summer, has rendered a service which deserves hearty appreciation from all students of economics, and especially from students of the fiscal question. The book is one that clears away misapprehensions and stimulates thought." Sheffield Independent.

"Professor Nicholson examines very lucidly the operation of these Laws as a part of the general policy of the country. He points out that they did not steady prices or benefit the farmer, that they did not prevent the flow of labour from the country to the towns, and that they did not make the nation independent of the foreign food supplies. "-Newcastle Chronicle.

"Every one of the divisions of the book is worked out with care, and with many illuminating flashes from the author's wide reading and keen grip of principles."-Glasgo:v Herald. 


\section{RATES AND TAXES}

AS AFFECTING

\section{AGRICULTURE}

BY

J. S. NICHOLSON, M.A., D.Sc.

Fellow of the British Academy

Professor of Political Economy in the University of Edinburgh

AUTHOR OP "EFFECTS OF MACHINERY ON WAGES,"

"THE histoRy OF THE ENGLish CORN LAWs," zTC., ETC.

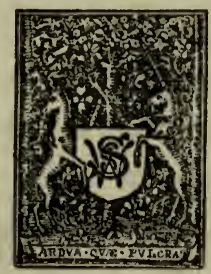

LONDON

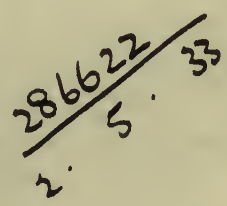

SWAN SONNENSCHEIN \& CO., LIM.

NEW YORK: CHARIES SCRIBNER'S SONS

1905 


\section{WORKS BY THE SAME AUTHOR.}

THE HISTORY OF THE ENGLISH CORN LATS. 2s. 6d.

(Sonnenschein.)

THE EFFECTS OF MACHINERY ON WAGES (2nd edition, revised).

2s. 6d. (Sonnenschein.)

PRINCIPLES OF POLTTICAL ECONOMY.

(A. \& C. Black.)

Vol. I. (2nd edition), Production and Distribution. 15 s.

Vol. II. (2nd edition), Exchange (including International Trade). 12s. $6 \mathrm{~d}$.

Vol. III., Economic Progress and the Economic Functions of Government (including the Principles of Taxation and Expenditure). 15s.

ELEMENTS OF POLITICAL ECONOMY. One vol., 75. 6d. net. Based on the larger work.

(A. \& C. Black.)

MONEY AND MONETARY PROBLEMS (6th edition). 7s. 6d.

(A. \& C. Black.)

BANKERS' MONEY. 2S. 6d.

Do.

STRIXES AND SOCIAL PROBLEMS. 3s. 6d.

Do.

HISTORICAL PROGRESS AND IDEAL SOCIALISM. 1s. 6d. Do.

'TENANTS' GATN NOT LANDLORDS' LOSS. 4s. 6d.

(Douglas.)

INTRODUCTORY ESSAY AND NOTES to edition of Adam Smith's

"Wealth of Nations." 3s.

(Nelson \& Sons.)

INTRODUCTORY ESSAY to edition of Friedrich List's "National

System of Political Economy." 6s. net. (Longmans \& Co.)

THE TARIFF QUESTION, with special reference to Wages and Employment. 6d. (A. \& C. Black.) 


\section{PREFACE}

This volume is based on the Gilbey Lectures delivered in the University of Cambridge in the May Term, r 905.

Although the subject is treated with special reference to agriculture, the main object is to consider the principles which should be applied in the reform of English local taxation. The Report of the recent Royal Commission on Local Taxation has shown conclusively that the present system is in urgent need of reform, and the evils are so deep-seated that a critical examination of the foundations is a necessary preliminary to any thorough amendment. Such a preliminary inquiry as is here attempted involves an examination of the origins of the system. We must consider what were the principles or ideas intended to be applied, and how far the application was modified by practical difficulties and historical accidents. Only 
in this way can we understand how much of the present system is primá facie suitable to the changed conditions of modern times.

The application of the historical method must be supplemented by a critical analysis of the ideas and methods which are at present put forward as the basis of practical reforms. In this connection the most difficult problem is to determine the principles which should govern the readjustment of local and national taxation.

To some people any reference to history seems only of antiquarian interest, and any consideration of principles academic or doctrinaire. But in fact, on the question of the reform of local taxation, the most simple popular arguments involve references to history and to abstract economic theories. The popular idea, for example, that rates are a hereditary burden on land, that they are paid out of the unearned increment, and that any remission must simply go into the pockets of the landlords, takes for granted a view of history that is unsupported by facts, and a series of abstract economic 
theories that are only true under hypothetical conditions.

The conclusions and criticisms here offered may not be accepted, but they will serve the purpose intended if they help to confirm the presumption that in the reform of local taxation nothing can be taken for granted.

From one point of view, the present work may be considered as supplementary to the "History of the English Corn Laws" published last year. The general conclusion of that work was to the effect that in their origins the various corn laws were reasonable from the standpoint of the time, but that under present conditions the ideas on which they were based are undesirable and impracticable.

The general conclusion of the present argument as affecting agriculture is that the continuance of the old system of local taxation imposes an inequitable burden on the agricultural interests, and indirectly is detrimental to the public good. The practical unanimity with which the Agricultural Rates Act was continued in the last 
session of Parliament seems to show that any fiscal relief to agriculture must be sought for in the remission of internal differential taxation, and not in the illusory imposition of taxes on the foreigner.

In the historical parts of the work I am much indebted to Dowell's " History of Taxation and Taxes," and to the admirable monograph of Dr. Edwin Cannan on the "History of Local Rates in England"; and throughout I have found of the greatest use the Reports, with the Memoranda (especially the "Memoranda in the Classification and Incidence of Imperial and Local Taxes") and corresponding evidence of the recent Royal Commissions on Local Taxation and on Agricultural Depression. Mr. Clark, M.A., has kindly corrected the proofs and verified the references.

\section{J. SHIELD NICHOLSON.}

UNIVERSITY OF EDINBURGH, September, 1905. 


\title{
CONTENTS
}

\author{
CHAPTER I \\ GENERAL PRINCIPLES
}

INTRODUCTORY: The case of agriculture must be taken in connection with the whole system of national and local finance. Report of the Royal Commission on Local Taxation. The Agricultural Rates Act only a makeshift expedient. Local Finance full of anomalies and inequalities which are increasing. The equity of any tax cannot be judged by itself. In dealing with taxation, equity not the only consideration. Other canons of taxation and the influence of sentiment, history and custom. The popular idea that certain rates and taxes form a hereditary burden on land must be examined in the light of history.

\section{CHAPTER II}

\section{NATIONAL TAXES}

THE legal idea that all land is held under the Crown has no bearing on taxation. The Crown, as representing the nation, gradually abandoned its feudal privileges and the ancient demesne lands. The process of denationalisation completed and legalised two centuries ago. Taxation (in the true sense) of land of very ancient origin, but always associated with taxation of personality. The land tax originally part of a general income tax. On the whole, down to I 894 agricultural land taxed less than other forms of property for national purposes, especially as regards the Death Duties. Protection and bounties also given. Peel's opinion on the claim for relief on the abandonment of protection approved by Henry Sidgwick. As regards national taxation, history shows no peculiar hereditary burden on land-rather the contrary. At present no unearned increment over the greater part of the agricultural land of England. - . . - . . 


\section{CHAPTER III}

\section{LOCAL TAXES}

Most rates based on the Act of $160 \mathrm{r}$. This intended to establish a local income tax for the relief of the poor. Stock-intrade not legally exempted till 1840. Rents paid by occupiers originally taken as a test of income. Gradually confusion between persons and things. Rates only affected owners indirectly, and no hereditary burden on owners as such. Undue narrowness of the basis of local taxation began to be recognised more than sixty years ago. Relief to ratepayers gradually increased. In 1842-3 amount of local revenue raised from rates 97 per cent. as against 3 fer cent. from national funds. In $1891 \cdot 2$ the proportions were 79 per cent. and 21 per cent., but largely neutralised by the increase of rates in the $\mathcal{L}$. More relief needed especially for agriculture under present conditions. Methods of relief and reform of the present system.

\section{CHAPTER IV}

\section{THE INCIDENCE OF TAXES}

INCIDENCE of fundamental importance in reform of present system. Taxes on agriculture cannot be transferred to consumer. Examination of the theory that rates fall entirely on rent. Only true under hypothetical conditions. Greater part of agricultural rent in England is profit on capital sunk in the land. Of rent actually received 40 per cent. is spent on outgoings, and in addition one-fifth of the net rental on improvements. Taxes on rent increase agricultural depression. In general some of the burden falls directly on the occupiers, who also suffer indirectly. The Agricultural Rates Act benefited the tenants. During the last fifty years agriculture has not prospered compared with the industries in the towus, and is less able to bear any increase of taxation. In any reform of local taxation greater relief ought to be given to agriculture - 


\section{RATES AND TAXES AS AFFECTING AGRICULTURE}

\section{CHAPTER I}

GENERAL PRINCIPLES

The Final Report of the Royal Commission on Local Taxation was issued in Igor. A very able conspectus was presented of the burdens, anomalies and inequities of the present system, and a careful statement and examination was given of the principal remedies proposed. It is always dangerous to attempt to summarise in a few sentences the results of an elaborate inquiry of this kind, but it is still more dangerous simply to 
use the report for the extraction of material favourable to some particular case. People interested in agriculture will naturally turn to the paragraphs dealing with the burdens and the reliefs of that industry, and they will discover very easily that in the opinion of the Commissioners there are grievances that ought to be remedied. But they would be seriously mistaken if they think that by this simple process they have proved their case. It may well happen that the grievances of other classes and interests are more serious and more urgent in their claims for redress.

It is plain that the particular statements concerning agriculture must always be construed in connection with the general tenour of the report. And it follows that some attempt at a summary of the results is desirable before descending to this particular case. The most important and general conclusion appears to be that local taxation 
ought to be relieved, wholly or partially, of the provision for various services of a national and onerous character. Anyone who reads the evidence on the existing conditions will probably agree with this opinion, and a general belief that such a redistribution of burdens is required is no doubt the first step to reform. But as soon as we pass from this very general opinion, and consider the means by which the redistribution is to be effected, unanimity is replaced by conflict. To take but one example, it is found that two principal methods of relief to local taxation are at present in use. By one of these methods a grant in aid is given to the local authorities for certain purposes from the consolidated fund; by the other, the yield of certain specified taxes is assigned to the localities, the funds being partly allocated to particular purposes, and partly given without conditions. The opinion of the 
Commissioners was divided on the merits of these two methods of relief. There are, besides, variations in these methods according to variations in the proportions of fixity and control, both as regards the amount of the relief and the allocation to different objects. The actual complexities of the system are so great that in the separate report by two of the most able members of the Commission (Sir Edward Hamilton and Sir George Murray), it is stated: "It is not easy to explain the anomalies of the present system, or rather systems, of allocation. Perhaps it is not too much to say that it might not have lasted as long as it has, if its obscurity and complexity had not made it almost impossible for the public to follow." ${ }^{1}$

It is plain that whilst it is generally agreed that relief should be given to the ratepayers, there is no general agreement as to the

1 Final Report, p. I1 5. 
methods. There is also further disagreement as to the claims of ratepayers inter se, e.g., rural and urban.

These difficulties, no doubt, arise largely from the complexities of the present system of local finance, and if we seek for one general explanation of these anomalies and complexities, it is found in the fact that particular remedies have been provided for particular grievances without any regard to, or co-ordination of, principles. Each case has been dealt with on its own merits.

With the breakdown of local barriers, and the increase in national functions assigned or delegated to local authorities, this haphazard method, or want of method, cannot be continued. The reform of local taxation must be carried out on broad principles, and the methods adopted must be capable of continuous readjustment to varying conditions. 
It may be objected by the agriculturist that he is well satisfied with the principle of the Agricultural Rates Act of 1896 , and that all that is required is to make the relief correspond to the advance in the rates. Since 1896 , in most places the rates have been increasing, but the relief afforded depends on the rates actually imposed in the year before the passing of the Act. That is, the burden grows, but the relief is stationary.

But in reality, this Act is acknowledged to be of a make-shift character. It was passed as a temporary measure, and has been renewed for limited periods on the very ground that agricultural rates can only be finally dealt with as part of a complete system of reform. If it is true that in some cases the rates have doubled, and in most increased since the first passing of the Act, it follows that other 
things being the same, the relief afforded by the Act is not now adequate. All that can be said is that, but for the Act, the position would have been so much worse. If, however, there was a case for relief in 1896 , there is now a case for further relief.

But it is safe to assume that no further relief will be obtained except as part of a general scheme. Other classes and interests also call for relief. The worst of it is that there is no prospect of an overflowing exchequer, and without it an increase of relief in one direction can only mean an increase of burden in another.

It follows, then, that the case for agriculture cannot be treated in isolation, without regard to general principles and general conditions. And if my treatment appears too general, you must remember that at present you cannot 
become practical without an agreement on principles.

If relief to local taxation is to be given from national revenues, it follows again that, so far, the two systems of national and local finance must be treated together. It is futile to say that certain local charges must be thrown on the Exchequer, unless at the same time the sources of the additional revenue are indicated.

The simultaneous consideration of local and national finance seems also requisite from the point of view of equity. Opinions may differ as to the ideal of equitable taxation, but whatever view, or combination of views, is adopted, it is clear that national burdens ought not to vary merely according to localities. If, for example, additional revenue must be raised for war or defence, no one would propose that the income and other national taxes 
should vary according to the locality in which they happen to be collected.

In the same way, any other national burdens ought to be equitably distributed, and the mere difference of locality ought not to make a difference in the burden imposed on the individual taxpayers. And this throws us back on what is after all the fundamental principle that must be applied throughout: the principle, namely, that all taxes fall on persons and not on things. By this time, this principle ought to be a commonplace, so often has it been insisted on in the present controversy; but as a matter of fact, it is constantly forgotten.

The very reference to the Royal Commission is open to the criticism that it suggests that taxes fall not on persons but on things; they were to report whether all kinds of real and personal property contribute equitably to 
taxation raised for local purposes. In this case, the Commissioners themselves pointed out the importance of the principle of personal burden, but they did not always follow it to the logical conclusion; and in popular controversy, the point most discussed is still literally whether different classes of property are equitably taxed.

The fallacy involved in this point of view may be illustrated by reference to a case that will call for repeated consideration in different forms. It is a grievance of the agricultural ratepayers that poor-rates, and similar rates, are levied on the net rental of the cultivated land, and they contend that land is as much the raw material of the farmer as wool or cotton is of the manufacturer. It is alleged that one form of property is taxed whilst other forms used in a similar way escape. Thus the farmers - the manufacturers of food-seem to have a 
special grievance against the manufacturers of clothes and other things.

In the same way, it is urged that the shopkeeper is not rated on his stock-in-trade, whilst the farmer is in effect so rated because his rent is payment, not merely for land at its prairie value, but as inextricably combined with various forms of capital. Suppose, however, that in fact the farmers, as a body, are able to transfer this part of their rates to the landlords, then this special grievance disappears, so far as they are concerned, and is transferred to the owners of land. The real difficulty is not that land is taxed, but who really pays the tax-landlord or occupier. The principle that taxes fall on persons and not on things is in effect the basis of the distinction between primary (or nominal) and ultimate (or real) incidence. The classification of taxes at best only gives an indication of the primary or nominal 
incidence. The real or ultimate incidence of what is apparently the same tax will vary according to the economic principles that are applicable, and also according to the facts of the case.

Still, even when it is fully admitted that taxes fall on persons, it may be objected that it is not equitable to impose a tax for national purposes on the occupiers (or if they can shift it on the owners) of one great class of property only, which is classed as rateable chiefly because it is visible and immovable. Those who do not own or occupy this rateable property escape altogether, and so far as the rateable value is not adequate evidence of the total ability of any ratepayer, he also escapes. It needs no proof or illustration that a good deal of the local charges for onerous and national services are not paid in proportion to the total ability of the payers, even when 
only those in the same rating area are considered.

We must next notice, however, that this, of itself, is not a conclusive objection to the method adopted. Inequity of some kind appears throughout the whole range of taxation. ${ }^{1}$ The abstainer from drink and tobacco and other taxed commodities escapes a large part of imperial taxation. The total exemption from income tax of incomes below a certain amount is obviously inequitable, especially as compared with the incomes only slightly higher that only obtain a partial remission. At the present rate of Is. in the $£$, a person with $£ 200$ a year will pay $\AA^{2}$ in income tax (that is on $£ 200$, less $£$ i6o), whilst a person with $£$ ío

1 We cannot argue that the comparative absence of complaints on imperial taxes shows the equity of the system (Sir E. Hamilton, Mem., p. 52); it may merely show the ignorance or the hopelessness of the taxpayers. 
pays nothing. Inequities of a similar kind arise in the case of licenses of all kinds, certain classes pay whilst others escape free.

It is a much more serious objection, on the ground of equity, to the present system of imposing local rates for national and onerous services that, from the nature of the case, the charges vary from place to place. Persons with the same incomes, earned in the same way, pay different rates simply according to their locality. The education rate, it is said, varies from $3 \mathrm{~d}$. to more than 3 s. in the $£$. If education is properly regarded as a national charge, then such local differential taxes are inequitable. It would be equally unfair to vary the inhabited house duty, imposed for general imperial purposes. Everyone knows it is uniform from place to place, and if so, why should not rates also 
be uniform, so far as levied for national purposes ?

One answer to this, and to many other questions on the equities of finance, both national and local, is that the canon of equality, though placed first by Adam Smith, is not the only canon of taxation, and cannot always be assigned predominant importance. Adam Smith himself asserted that certainty was often to be preferred to equality, and besides certainty there are in Adam Smith's list the canons of convenience and economy. The great merit of indirect taxes, such as taxes on tea or sugar, is that they are collected from the ultimate payers, namely, the consumers, in insensible portions. It is well known that owing to this very simple characteristic of convenience to the payer, indirect taxes can be increased when the limits to the increase of direct taxation have already been passed. 
It is probably true that the smaller the income, so much greater is the relative inconvenience of direct taxes. This is one reason why the system of compounding the rates by which they are paid as part of the rent has been adopted in the case of small rentals. The occupier does not notice the rates when they are apparently part of the rent, just as he does not notice, and does probably not know, that the greater part of the price of his drink and tobacco is caused by imperial taxation. The term convenience should be construed in a large sense, and in this sense, taxes may be said to be inconvenient if they offend the sensibilities of people. In this sense, the taxes which eventually lost to us the American Colonies were, on their imposition, highly inconvenient to the colonists. The real burden was nothing, the outrage of the sense of justice and dignity was immense. 
It has been proved over and over again that in taxation regard must be paid to sentiment, and there is no question that in any reform of local taxation regard must be paid, not only to the real ultimate incidence, but to the apparent incidence and the corresponding sentimental disgust. From this point of view, a good deal of irritation would be allayed if the rates, which, as it is, are supposed to be transferred from the occupier to the owner, were actually and directly collected from the owner, or at any rate, were definitely and legally deducted from the rent. The operation of an economic tendency, as will be shown more fully presently, is, in general, not clearly seen or fully understood by the parties most concerned. Economic tendencies, again, are always liable to be counteracted, and this is specially the case in the transference of taxes. And people can see well enough 
when the favourable tendency breaks down in their own case, and they suffer from a so-called exception.

The point I am labouring may be made clear by an illustration taken from a theory of taxation which has been strongly held in the past, and has still some influence. I will give the theory in the form in which it is asserted by Sir Edward Hamilton towards the conclusion of his excellent Memorandum on the classification and incidence of taxes prepared for the Royal Commission on Local Taxation. "Perhaps," he writes, "there is more truth than is popularly supposed in the optimistic theory of general diffusion, which is, to use the words of an American economist, that taxes equate and diffuse themselves, and if levied with certainty and uniformity, they will, by a diffusion and repercussion, reach and burden all property with unerring certainty and 
equality." 1 So far, Sir E. Hamilton, but personally, I am inclined to think there is much less truth than is often supposed in this diffusion theory. It may serve, however, very well for an illustration. Suppose, then, that this theory of diffusion is really sound, and can be proved to the satisfaction of all economists and statesmen, and even of the mass of intelligent electors. Still it is safe to say that no statesman-not even the leader of a revolution-would venture to put it into practice. Sentiment would be too strong. He might apply the single $\operatorname{tax}$ to the big landlords, but never to the small and middling. Generally speaking, the person who actually pays a tax does not believe in the complete transference of the burden, so far as his particular tax is concerned. A shopkeeper might believe in the diffusion of a tax on land

${ }^{1}$ Mem., p. 52. 
values, but not of a tax on stock-in trade.

The canon of economy must also be interpreted largely; that is to say, account must be taken of all the various expenses, direct and indirect, that are involved in the imposition and collection of a tax. In many cases, when the indirect effects are considered, the cost is greater than the real net revenue. The great financial reforms instituted by Sir Robert Peel consisted in the main of the abolition of a mass of unproductive taxes, and the substitution of those in which the indirect restraints on trade and industry were reduced to a minimum. It may be argued that this process of simplification was in the end carried too far; but there can be no two opinions that the tariff which was destroyed had become hopelessly intricate and extravagantly wasteful. Altogether apart from 
other reforms, a similar simplification and reorganisation is required as regards local finance.

The consideration of the canon of economy suggests a natural transition to the principles of expenditure. The greatest master of finance this country has produced, asserted that good finance consists rather in the spending than in the raising of money. On the present occasion the subject of expenditure will only be touched on so far as necessary in dealing with taxation. The connection is of course very close, and in my opinion, for every rule of taxation there is, or ought to be, a corresponding rule of expenditure. ${ }^{1}$ Take the fundamental principle of equity. In estimating the real burden of taxation we ought to deduct the benefits that are derived

${ }^{1}$ See my "Principles of Political Economy," Bk. v., chaps. xv., xvi. 
from the corresponding expenditure. And this is equally necessary whether we consider classes, industries, localities, or even individuals. From this point of view, the rates or taxes that are classed as onerous to one set of people ought to be considered as beneficial to other classes. Take the rates and taxes that are imposed to meet the expenses of education. It is plain that the greater part of the working classes must receive more benefit (measured in the cost of the education of their children) than loss, from the increase of taxes for this purpose. This is quite clear, because a large part of the funds are obtained from people who obtain no share in the benefit. In other words, if the people who obtain free education for their children had to provide the funds by fees, the fees would amount to much more than their share in the rates and taxes. Personally, I am of opinion that 
it was a mistake to abolish the fee-system altogether. All that justice required was to make ample provision for cases of necessity. The education of children ought to be a first charge on the parents-a necessary as much as food and clothing. No one apparently at present is prepared to propose universal free meals and free clothes; it is admitted that a distinction can be made between the deserving and the undeserving, and it is generally said that the parents are to be made primarily responsible. It is a pity the discovery was not made before. It is now too late to go back on this part of the educational system; free education (at any rate, elementary) has come to stay. But in considering the equities in the readjustment of local and national taxes, we ought certainly to take account of the fact that the benefit of the education taxes is directly 
obtained by certain classes only. If it is said that the nation will also gain ultimately, the reply is that the nation would have gained still more if the parents had been compelled to provide the education at their own expense, and not at the expense of other people.

In the prolonged controversy that has taken place on the reform of local finance -and the controversy has been going on for at least seventy years-no position has been more clearly established than that a distinction should be drawn between the rates and taxes that are raised for onerous and beneficial services respectively. The point is that education taxes are beneficial to the classes that receive free education, and onerous to the classes that do not. The principle of betterment might be applied to children just as much as to lands and houses. 
From this point of view, it becomes still more clear that the transfer of so-called onerous charges from local to national funds is by no means so simple as at first sight appears, even when equity alone is considered. Unless account is taken of the corresponding expenditure and benefit, the readjustment might cause even greater anomalies and inequities. There are no doubt certain classes of public expenditure in which no benefit can be assigned to individuals or classes, or if there is any special benefit, it is purely accidental. The standing example of such purely onerous charges is the expense of a great war. Even in this case, however, certain industries may benefit, and if taxes could be so arranged these special gains might well be the objects of special taxation.

In more purely beneficial expenditure we have the exact counterpart to the principle 
that taxes fall on persons in the maxim that benefits also fall on persons, and equity demands that if possible the bearers of the loss, or payers of the tax, should also be the receivers of the benefit and conversely.

But as in taxation so in expenditure, we must consider other canons besides that of equity. In this case, also, certainty and economy are often of greater importance. Public funds ought really to be given to the objects for which they are intended. Evasion must be guarded against as rigidly as in taxation. If grants in aid of rates are given from the central funds, the precise objects should, as a rule, be specified, or there is a danger of malversation. The canon of economy is obviously of fundamental importance throughout. Any waste in expenditure means more taxation. Inefficiency, also, means more taxation, and generally every fault in expenditure means not only 
an offence against equity and public good faith, but an offence against economy, with the penalty paid by the taxpayer.

One of the best methods of securing economy and efficiency in expenditure is in making the connection between public expenditure and the consequent burden of taxation as clear as possible to the parties most interested; that is, the payers of the taxes. That is supposed to be the one great advantage of local rates over national taxes. And this is the reason why most reformers, who advocate on the grounds of equity a transfer of charges from local to imperial funds, still think, on the grounds of economy, that the transfer should be only partial. It might be more in conformity with equity to make the relief of the poor entirely a national charge, but it is contended that if this were done, the consequent extravagance would result in great loss, and eventually 
even equity might be infringed to a greater extent than under the old system.

In theory, there is no reason why a complete separation should not be made between the administration and the expenditure of funds on the one side, and their provision and collection on the other. The State might delegate any functions it thought desirable to the local authorities, and provide them with the requisite funds entirely from general taxation. A redistribution of functions and revenues of this kind is at the basis of most of the popular demands for the reform of local taxation and government. What is desired is more local control over the expenditure of greater national funds.

The great objection that is principally urged against such schemes is that the connection between the service and the real cost may be overlooked. Even in the case 
of local rates, it is said, the connection is often lost sight of, but with taxes and grants from the Exchequer the connection may never come into sight at all in the majority of cases.

People, it is contended, naturally look on a grant from the Treasury as a gift from heaven; it is the sunshine that costs nothing, taking the place of expensive coals. And so long as this is the popular attitude towards the grants made by the central authorities, it is maintained some part, at least, of the local contributions that have been customary should be retained. When new functions are imposed, involving new burdens, the case is, of course, somewhat different; but even here it is urged that it is a safeguard that cannot be dispensed with altogether without the risk of loss. I shall return to this question later on. At present, my point is 
that economy as well as equity must be considered.

Finally, altogether apart from the general principles that ought to be observed alike in taxation and in expenditure, regard must be paid, not only to existing institutions, but also to the historical conditions under which they arose. And this is specially true of this country; alike in government, in taxation, and in expenditure we have to take the growth and history into consideration.

It is true that there is no prescription of institutions, and indeed, under the bias of the theory of evolution we might almost say that the presumption in favour of old institutions has been reversed, and this generation is inclined to argue that what was suitable under the simpler conditions of old times, is not suited to the changed conditions in which we live. All this may 
be admitted in general terms; "changed conditions" has always been the war-cry of the reformer; but neither the general theory of evolution nor commonplaces about "changed conditions" will take us very far in dealing with the actual problems of finance. The reference to real financial history is a very different matter, and in every one of the canons of taxation, and the corresponding rules of expenditure, the historical influences must be reckoned with.

For the purposes of illustration we may take the canon of equity, which is always the canon which is most appealed to by impatient reformers; they look to the ideal and overlook the means.

As already observed, the reference given to the recent Royal Commission was "to inquire into the present system under which taxation is raised for local purposes, and to report whether all kinds of real 
and personal property contribute equitably to such taxation." My present point is that the equity of the present system cannot be considered without reference to the conditions under which it arose. Most people would admit-and at any rate, in this country, every responsible statesman would admit-that in any reform regard must be paid to existing contracts. But in no contract can every point in the agreement be recorded in extenso. In commerce, it may be said that every contract implies a reference to well-understood customs. In effect, a large part of mercantile law has arisen from the codification of the customs of merchants. In contracts dealing with the transfer or the hire of land, from the nature of the case, as a rule, the terms are much more explicit, but even in this case, a good deal must be supplied by the general law and a good deal by custom. 
In the case of property in land and tenancies of various kinds, very great injustice has been done in the past by too literal interpretation, or by reference to legal principles which were not really relevant, to the neglect of the illdefined rights of customary tenants. English economic history furnishes illustrations on a large scale, and the English, in perfect good faith and perfect ignorance, made similar illustrations in India. On the other side, quite recently in Ireland, and to a less extent in Scotland, legislation has paid more regard to the custom of the country than to the letter of the law, in the readjustment of the relations of landlords and tenants.

One thing, however, is certain: that both the letter and the custom, ought to be considered if an equitable interpretation is desired. 
To come to the most important case in this controversy on the equities of local finance, it is said that many charges on land-the poor-rates, for example-are to be regarded, from the point of view of equity, not as taxes at all, but as rent charges reserved in favour of the public, or rather of the poor. The poor-rate has been described as "the first charge on land," and other rates and taxes have been described as "hereditary burdens." And these phrases have not been the inventions of the enemies of the landed interests, but have been accepted by responsible statesmen as indicating, at any rate, one of the elements that must be always considered.

In considering the question of relief to the landed interests, it is then of vital importance to consider how far this theory of hereditary burden 
is sound. This makes it absolutely necessary to look to the history, and that will be the main subject of the next chapter. 



\section{CHAPTER II}

NATIONAL TAXES

BEFORE proceeding to consider the historical argument on the "hereditary burden " theory, some notice may be taken of a quasi-legal argument, which is often popularly supposed to give a legal foundation for the exceptional taxation of land as compared with other forms of property.

If the law sometimes makes havoc of the principles of common-sense in the matter of taxation, common-sense in return sometimes makes havoc of the law. Blackstone long ago found it necessary to distinguish between the terms reason, reasonable, and the like, according to the popular and the legal usage, 
and if a divergence exists on what is or is not according to reason, we may expect similar differences when the reason is applied to particular cases. The result is, that if, as the lawyers say, it is never safe to apply commonsense directly to any case of law, in the same way, it is never safe to apply a legal maxim to a case of common-sense. These reflections are suggested by the separate report of his honour, Judge O'Connor, K.C., in the Final Report of the Royal Commission on Taxation. "On this point," he says, "the law of England is in accord with common-sense; and according to that law, land is not the subject of absolute property. No man is in law the absolute owner of the lands. He can only hold an estate in them, and that estate he holds only under the Crown, as representative of the community." In the sentences which follow, the position is still more emphatically laid down that "collec- 
tively, the land of England belongs to the people of England." All this sounds very like accepting the most extreme proposals for the recognition of the nationalisation of the land. If the land belongs to the people, surely the people have a right to do what they like with their own, and inter alia, to impose any taxation they please.

Anyone, however, who reads the reports of cases in which the people try to assert their supposed rights to the ownership of the land in the courts of law, will soon discover that in practice, if the national ownership of land ever existed (except as a convenient legal fiction), it has long since been abandoned. In the language of the people, the people have not the right even to look at the land which is said to belong to them, and at the instance of a private person, the right of access may be denied to the most beautiful scenery and to the most imposing historical monuments. 
In the Stonehenge case, the judge said the law was so clear that the case ought never to have been brought. It is, at any rate, quite clear that when the law of England says the land belongs to the people, it means something totally different from the popular conception of belongings and property.

In the same way, so far as the law is concerned, the people have not retained a peppercorn rent in the acres of England. The Crown may, in the eye of the law, be the owner of all the land of England, but it is not the owner of the rents, and there is nothing in the nature of a rent charge reserved to the Crown as representing the people.

The conclusion, then, is that, so far as the actual interpretation of the law is concerned at present, this supposed national ownership is of no pecuniary value.

The question next arises whether it would 
be equitable to give an economic meaning to this barren legal right of sovereignty. In the concrete the question, as now put, generally means: Ought "land-values" to be subject to exceptional or differential taxation?

This naturally leads up to the consideration of the historical argument. In the strongest form, this argument involves the idea that in virtue of this ultimate ownership by the people, certain exceptional burdens have always been imposed on land, and that land has been bought and sold on this understanding.

In the past, there have been notable cases in which the customary rights of the people of a locality have been sacrificed to the rights of private ownership because the private owners got the full advantage of the letter of the law, and the rights of the community were such as could not be 
properly formulated in the language of the law. Under present conditions, however, the tendency is to insist on the recognition of these ill-defined but equitable rights. And if it could be shown historically that there has in practice been some reservation of revenue from land in the form of customary taxes, although the custom was variable and ill-defined, the argument would have much weight when the whole system of taxation is under examination with a view to reconstruction.

The saying that an old tax is no tax, is often applied with special emphasis to the case of land. From this point of view, taxation of land is supposed to be of the nature of a rent charge, and the State is said to have the first claim, the private owner only having a second preference.

It is convenient and conducive to clearness to take separately national and local taxes. 
From the national point of view, the question may be considered first of all in connection with the abandonment of certain sources of revenue from land which formerly appertained to the Crown.

These revenues were of two kinds. In the first place, there were the demesne lands of the Crown, the manors which, in the ordinary sense of the term, belonged to the King. Originally this demesne land had been so valuable that the King could "live of his own," but successive kings granted away large portions, and in spite of the protests of the Commons, Elizabeth continued the process, and by the time of the outbreak of the Civil War under the Stuarts, the revenue from the demesne was only worth $£$ 120,000. Even this remainder was sold by the Commonwealth. On the Restoration in 1660, suggestions were made for the resumption of these lands, but they were met 
by the claims of bond-fide purchasers, and only a small part was recovered. Charles II. renewed the process of alienation, and in 1663 , the total revenue from this source was only $£$ 100,000.

In this brief history two points only require emphasis for the present purpose. In the first place, the demesne land had ceased to be an important part of the revenue for national purposes three centuries ago. Complaints had been made of the wasting of the ancient revenues of the realm, both by the people and by Parliament, but in vain. That is the first point, for good or evil the ancient demesne had been alienated centuries ago.

The second point is that once the alienation had been effected, recovery was impossible on account of the claims of bon $\hat{a}$ fide purchasers. It is true that for a long time there was a popular agitation for the 
resumption of the alienated demesne lands, but the matter may be said to have been finally settled in I702. ${ }^{1}$ By that time the actual revenue from demesne was very small, but there were chances of certain reversions and remainders falling in. An Act was passed which prohibited the alienation of any such land in the future, and also at the same time gave a Parliamentary title to the lands formerly alienated, and in which there was always some doubt as to the title. Up to this time the insecurity of the position of the grantee of the Crown lands had been such as to render them on sale or settlement worth less by several years' purchase than lands held under another title. From that date this difference disappeared.

It surely ought to need no showing that it would be utterly impossible, with any regard to equity, to attempt to go back centuries.

${ }^{1}$ Dowell iii., p. 65, etc. 
in the search for the original national revenues from the land.

Besides the demesne lands, however, there were certain revenues of a feudal character which pertained to the Crown as representing the nation. The meaning of these feudal payments had been lost, and the whole feudal system in its essence destroyed by the time of Elizabeth. But for the difficulty of finding a substitute, all these revenues would have been abandoned in 1610. They were in effect surrendered in 1660. In this case it was proposed that the lands relieved should be burdened with a corresponding tax, but again it was found that the practical difficulties, having regard to the claims of bonâ-fide purchasers, during the period when the dues had been falling into abeyance, were so great that in the end Parliament gave the King an excise duty on certain things instead. The value 
of the feudal dues surrendered was only about $£ 100,000$ per annum; like the demesne, they had been wasted time out of mind. The general conclusion is that by the beginning of the eighteenth century the Crown, as representing the nation, had lost practically all claim to revenue from land. So far land had been placed on the same footing as other forms of property. This was the recognition of the result of a long period of what may be termed denationalisation of the land. From some points of view, especially as regards urban land, this total abandonment may be a cause for regret. But on the other side, we have to place the benefits derived from the extension of the system of private property. Most economists would agree with Adam Smith that, at any rate, so far as agricultural land is concerned, it would generally be advantageous to expose the 
national lands to public sale, so that the advanțages of private ownership might be secured. ${ }^{1}$

The real cause for regret is that when the essence of the feudal system was abandoned, the legal forms were not also swept away. This, however, opens up a much wider question. For the present, it is enough to insist that the vague popular idea that the land of England belongs to the people of

1 "The revenue which, in any civilised monarchy, the Crown derives from the Crown lands, though it appears to cost nothing to individuals, in reality costs more to the society than perhaps any other equal revenue which the Crown enjoys. It would, in all cases, be for the interest of the society to replace this revenue to the Crown by some other equal revenue, and to divide the lands among the people, which could not be well done better, perhaps, than by exposing them to public sale. Lands for the purposes of pleasure and magnificence, parks, gardens, public walks, etc., possessions which are everywhere considered as causes of expense, not as source of revenue, seem to be the only lands in a great and civilised monarchy which ought to belong to the Crown "- "Wealth of Nations," Bk. v., chap. ii., Part I. (general conclusion). 
England, in the sense that the nation has a right to the whole or part of the rental, and that a special tax on land-values is only the assertion of this just claim, is in the light of history an absurdity. No doubt the people of England, or the Parliament in which the sovereign power of the people is vested, has the right of imposing any taxes whatever, just as it has the right of putting to death anyone of its subjects-simply to encourage the others. But in civilised countries the exercise of arbitrary power has long since been abandoned. Even in the matter of taxation, it is absurd to say that the State can impose any taxes it chooses, if that means that under the name of a tax it can appropriate the lands of individuals regardless not only of contract, but of well-established custom.

We must next consider, then, if special differential taxation of land is justifiable 
on the ground of custom in the widest sense. And again, we may take the national taxes first.

Taxes on land, in the modern sense of the term tax, that is as distinguished from any revenues in the nature of a rent charge, existed from very early times. The famous Dane-geld, levied in Saxon times ostensibly to repel the Danes, was a land tax, and there were other taxes of a similar character in Anglo-Norman times. It may be said that, before personal property existed to any appreciable extent in England, taxes were charged on land. Land taxes are as old as the cultivation of land. But the point is that as soon as personal property became of sufficient importance to attract the attention of the tax-gatherer, all these land taxes were merged in a general system of taxation, which applied equally to movables. The standing example is the Saladin tithe in 
I 88, which was a tax charged on rent, and movables in every parish. ${ }^{1}$ This plan of taking fractional parts, from a tenth to a fortieth of movable goods (or their value), was continued throughout the Middle Ages. Sometimes these taxes included the rent of land, but in general outside the towns they were levied on the cattle and crops of the landowners, and in the towns on the capital value of stock-in-trade and chattels. The rate of taxation that became usual was that by which the counties were charged a fifteenth and the towns a tenth of all goods-and we observe that the country is so far favoured. In the course of time a fifteenth and tenth meant simply a certain sum which was allocated to the different townships and counties according to old custom. These taxes were supplemented by what were called subsidies, which were intended to take account

${ }^{1}$ See Dowell's " History of Taxation," vol. iii., pp. 73, 75. 
of the change in values that had taken place since the amount of the fifteenths had become fixed.

Here, again, the principle was that the subsidy was raised by a pound-rate upon lands, and likewise a pound-rate on goods; and in the rates charged the land was favoured, apparently, at the expense of the towns. According to the schedules, every form of movable property (including plate and money) was to be taxed, but with land only the rent, and it was provided that no one was to be taxed both in respect of his land and of his movables-only one or the other. It is interesting to notice that the inequity of this system (as regards movables) was mitigated by the early adoption of the method of self-assessment. In the words of Bacon, the Englishman was the most master of his own valuation, and the least bitten in purse, of any nation 
in Europe. About sixty years after Bacon's death, another celebrated man, Pepys of the immortal Diary, recorded that he had got ready $£ 12$ for the tax-collector, but as he only demanded I2s., he did not think it necessary to discover himself. ${ }^{1}$

In the Commonwealth subsidies were collected monthly, and the plan was adopted of taking a pound-rate from the rental of land, and assuming that the capital value of movables yielded an income of five per cent. The value of merchandise and stock - in - trade was, of course, included. One feature of the method of collection is noteworthy, namely, that in every case the tax was collected from the occupiers of the lands and houses, but they had the right to deduct the part that was due from the landlord for his income from the rent. The payment of the tax was considered pro tanto

${ }^{1}$ Dowell, vol. iii., p. 29. 
a payment of rent to the landlord. The tenant, of course, had to pay the tax on his own profit, assumed to be five per cent. on the value of his movables. Absentees were rated double, both for lands and movables.

In this brief survey it is only possible to notice the leading cases that bear on the point at issue, namely, the supposed differential taxation of land as shown in history. In 1692-and we may say that the modern method of Parliamentary control of finance dates from the Revolution of 1689 - a tax of $4 \mathrm{~s}$. in the $f$ was granted to carry on the war against France. This was levied on the rent of lands and houses, but also on the stipends and salaries of officials, and on the income from movables estimated at six per cent. of the capital value. Stock on land and household furniture were not to be assessed, but of course stock-in-trade was included. This 
did not yield so much as was expected, and in 1697 a return was made to the plan of exacting so much from each localitythat is, every town and county. The plan to be adopted in each locality was this: A rate of 35 . in the $£$ was to be imposed on an assimed income from goods, merchandise, and personal property, every $£$ IOO in capital value being supposed to represent an income of $£ 6$, and the tax was also levied on salaries from offices and employments. Then-here for our purpose is the point of interest-the residue of the sums required was to be obtained by a rate on real property; that is, the rent of lands and houses.

This property tax of William III., which was originally intended to bear in the first instance on personal property and salaries from offices, and only to be supplemented so far as required by a tax on lands and houses, 
degenerated into what came to be known as the annual land tax. The simple truth was that owing to the practical difficulties of assessment, personal property slipped out of the reckoning, and real property being immovable and visible, came to bear the whole, and not the mere residue of the amount exacted from any locality. ${ }^{1}$

There are one or two other points about this annual land tax that deserve consideration. Although the amount was nominally so much in the $£$ of the rental, it was in fact not a tax but a rate. One shilling in the $£$ simply meant that, in round numbers, half a million was to be raised from the country as a whole, the amounts assigned to the particular localities being based on the yield of a certain year; then to raise this sum the localities must impose the rate that was necessary, which would 'See Dowell, vol. iii., p. 5 . 
be more or less than the shilling according to the sum assessed and the wealth of the district. When the rate was raised, say from Is. to 4S., it meant that the sum to be got from each district was increased fourfold. It did not mean that the State obtained a tax from all lands of $4 \mathrm{~s}$. in the $f$ on the actual rental.

We have here a repetition of mediæval experience, where the fifteenths and tenths, and later the subsidies, began as proportional income or property taxes, but soon became fixed sums due from localities, and raised by them by local rates. 'The annual land tax under William III. was originally a proportional property tax, and it came to be a fixed sum per shilling of the nominal rate imposed. A shilling rate meant half a million and a 4s. rate meant two million in round numbers (the precise figures were a little less). As 
the allocation was also fixed, it soon became extremely inequitable as between the taxpayers in different districts.

It must not be supposed, however, that when personal property escaped the annual land tax it escaped all taxation for national purposes. Since the old income tax had dwindled into a land tax, what was in effect a new income tax was imposed, in which the Englishman was no longer to be the master of his own valuation, which mastery had caused all the trouble. What was wanted was some visible unconcealable sign of income. This gave rise first to the hearth or chimney tax, the wealth of the taxpayer being supposed to be indicated by his fires. It may be said that of all the tax-gatherers the chimney-man ${ }^{1}$ was the most odious.

Accordingly, the chimney tax gave way

1 Dowell, vol ii., p. $3^{8}$. 
in time to the window tax. The windows were taxed of course simply as a convenient, if rough, measure of wealth. There were variations and exemptions at various times (e.g., for a long time the windows in farmhouses were not taxed), but the tax survived as an important source of revenue down to $185 \mathrm{I}$. Long before this it had been supplemented by a definite tax on the annual value of inhabited houses.

It is not necessary to show more in detail what is abundantly plain in general, namely, that down to the end of the great war in I 8 I 5 , when practically everything was taxed, land was not, on the whole, subject to any differential or special taxation as compared with personal property - that is, for national purposes. If we look, as we ought to do, at the whole burden imposed on the owners and occupiers of agricultural land, as compared with that imposed on the traders 
and manufacturers in towns, the latter, no doubt, paid more in the way of national taxes in proportion to wealth and population. In 1798 the land tax was actually converted into a perpetual rent charge open to redemption, but as a matter of fact, even in this case the idea has been abandoned that this land tax is a first charge on the rent, and it is not now exacted beyond a certain proportion. ${ }^{1}$

So far the national taxes have been considered only as affecting the income and property of the living. The death duties, however, have also a long history, but the history down to the Finance Act of 1894 need not detain us long for the purpose in hand. We are at present in pursuit of the idea or the fallacy that as a matter of history, or of custom as therein revealed, land has been subject to differential taxa-

1 See Report on Valuation, $\Gamma$., 107. 
tion of such a kind that it may be equitably looked on as a rent charge-that, in fact, there is somewhere to be found an infinitely larger land-tax than the remnant dealt with by Pitt, and that this immense revenue ought to be considered as a rent charge in favour of the public. This potential rent charge is certainly not to be found in the death duties. For down to the reforms by Mr. Goschen in I888, and Sir William Harcourt in 1894 , it is notorious that the death duties had been in favour of land as compared with other things. The whole subject is smothered with legal cobwebs, or legal reasons and distinctions. But the broad fact remains that real property paid less than personal; and most interests in landed property were ranked under the former class.

The truth is, that for a long time as regards this part of taxation (the death 
duties), land was supposed to be unduly favoured; and if we take as the test a simple comparison of the duties paid, the charge is just.

It is, however, always necessary to consider the tax system as a whole, and this exceptional treatment of land was generally justified by a reference to the burdens imposed for local purposes. And this must be deferred till we have examined the history of local rates.

To complete the survey of the national taxes, as affecting agriculture, we have next to notice the taxes that were imposed with the express object of giving a benefit to agriculture.

Hitherto we have considered agriculture as affected by taxes imposed on land, and these taxes have been naturally considered as a burden. The main object of taxation is, of course, to provide a revenue for public 
purposes, but sometimes incidentally, and sometimes principally, taxes have been used to promote other objects. Taxes have been imposed as penalties or preventives. Taxes on stimulants are supposed to be of this character. The demand for the special taxation of unoccupied building land is supported partly (perhaps mainly) on the idea that the penalty would throw more land on the market, and thus lower its price.

Taxes have also been used to encourage particular industries. Protection has been given against foreign competition, and bounties (the proceeds of national taxation) have been given to encourage some particular industries. In the past, both of these plans were adopted for the benefit of agriculture. One of the reasons given for the bounty on corn was that land had to provide the greater part of the revenue of the State, and 
that therefore agriculture, which earned the greater part of this revenue, should be fostered by the State. As the whole policy of the Corn Laws has been treated by the present writer in another work, ${ }^{1}$ it must suffice on this occasion simply to indicate the place of these expedients in the system of taxation as a whole. It was generally recognised that down to 1846 agriculture, and the land devoted to it, had received special benefit from the protectionist system. When this system was abandoned, Sir Robert Peel thought that some compensation should be given to the landed interest, and with this view, certain local charges which had formerly fallen on land were now met from the national Exchequer. ${ }^{2}$

This policy was not only approved of at the time and carried into effect, but it was 1 "History of the English Corn Laws." (Sonnenschein, 1904.) 2 Mem., p. I 2. 
justified in the memorandum submitted to the Commission on Local Taxation by the greatest modern authority on the ethics of politics, namely, the late Henry Sidgwick. "I think," he says, " that the abandonment of this policy in 1846 gave the owners of agricultural land an equitable claim to be relieved from such part of the special burden of local taxation as it would have been inequitable to impose on them if the system of local taxation had been arranged de novo; and that the interval of time that has elapsed since 1846 is not sufficient to impair materially the force of this claim, especially since the tendency of free trade to lower the value of agricultural land has only been gradually realised" (p. II 2). The sentences I have quoted form the conclusion of a long and difficult argument on the question whether long-continued burdens on land can be considered to have been converted in the course 
of time into a kind of equitable rent charge in favour of the public. This, I may remind you, is the the main question involved in the historical argument to which this chapter is devoted, and at this point, it may be convenient to summarise the results obtained, so far as national, as distinct from local taxes, are concerned.

In the first place, the vague popular notion that the State is, so to speak, the ultimate owner of all the land in the country, or that the land of England belongs to the Crown as representing the people of England, and that therefore all or part of the rent also belongs to the people, and may be equitably taken in the name of special taxation, this notion is from the point of view of history absolutely unfounded. The Crown abandoned its own demesne lands, except an insignificant fragment, centuries ago, and similarly also it 
abandoned its right to a variety of feudal dues from other lands. For all practical purposes the Crown, in the name of the people, has no more right to claim part of the rental of land than it has to claim part of the rental or income from other forms of wealth, e.g., ships or machinery. In the last resort, the State has of course the right to take any form of property it likes for the public use, but to exercise this right in an arbitrary way, regardless of equity as between different individuals, would be to cause an indirect loss in security, that would altogether outweigh the direct gain of the confiscation. If, then, the titles to land, so far as the idea of private ownership is concerned, have in fact been settled for centuries, we cannot now go back and bring in the long abandoned claims of the State. This idea of State ownership may possibly be of some use from the point of 
view of legal symmetry, and, in the eye of the law, and according to the reason of the law, and in the language of the law, it may have some meaning, but it has no meaning that is pertinent in the question of the practical taxation of land.

Again, if we ask if the taxes imposed by the State on land, seeing that they have been continued for centuries, cannot be regarded as a kind of rent charge, the answer again is, if we refer to actual history, that so far as the national taxes are concerned, such taxes are on the same footing as taxes on other forms of property. Taxes on the rents of land were always accompanied by similar taxes on other forms of income, and, as we saw, a hypothetical income was assigned to the capital value of various kinds of movables for the purpose of taxation. But we may go further in the case of land. 
Down to our own times (1894), on the whole, for national purposes, land and agriculture were taxed less in proportion than other forms of property and other industries. If, then, we are to appeal to historical precedent only, so far, a case would be made out not for special hereditary burden but for special hereditary relief. And stated broadly, the historical justification of this favour is, that agriculture is of such vital importance to a nation that anything that benefits agriculture must benefit the nation as a whole.

So far as agriculture itself is concerned, this argument might appear reasonable, even at the present time; but popularly it is supposed that any relief given to agriculture goes to swell the "unearned increment" from land. The distribution of any relief to agriculture, as between the 
different interests of landlords and tenants, must be reserved for the concluding chapter on incidence; but in this very general historical survey, it may be pertinent to observe that under present conditions the popular idea that there is a constantly increasing unearned increment from land, owing to the general progress of society, is the reverse of true in the case of agricultural land. The point received careful examination from the last Royal Commission on the depression of agriculture; and in their report (I898), ${ }^{1}$ after quoting the distinction drawn by J. S. Mill between economic rent proper, that is paid for the natural qualities of the land, as distinct from what may be called profit rent, or what is really interest on the capital sunk in the land, it is stated that over a very considerable part of this 
country true rent has entirely vanished. This view is supported by statistics drawn up by Sir Robert Giffen, one of the members of the Commission. "It may be fairly assumed from the evidence that in the opinion of our eminent colleague the present rental value of agricultural land (i.e., the gross rental) is appreciably less than it was fifty years ago, notwithstanding the continuous expenditure of capital on the equipment and improvement of farms and the reclamation of land." 1

Then again, it is said: ${ }^{2}$ "Any statement as to the diminution of the rental of land fails to express in an adequate degree the extent of the landowners' losses." 3

$$
1 \text { P. } 24 . \quad 2 \text { P. } 26 .
$$

3 "In many cases where rents have been readjusted and much reduced, further remissions of rent have been found necessary; gifts of feeding stuffs and manures have been made, arrears of rent have accumulated, and not infrequently these have been written off. Farms have 
The conclusion, then, is that for the last half century instead of an unearned increment from agricultural land, there has been an unearned (and certainly undeserved) decrement.

been thrown on the owners' hands in an impoverished condition, and it has been found impossible to let them. The outgoings of tithe rent charge and taxes, with the cost of necessary repairs, have not diminished in proportion to the rent, while the demands of the tenants for additional buildings and drainage and other improve. ments have increased. It is clear then that the $\mathrm{n}: \mathrm{t}$ income of the landowner has fallen off to a far greater extent than is shown by a comparison of the gros; rental now and at a former period." - "Commission on Agricultural Depression." Final Report, p 26. 


\section{Supplementary. Note on the Estate Duties}

As regard the estate duties, or death duties, the real effect of the Acts of 1888 (Goschen) and 1894 (Harcourt) has been to impose greater burden on land, including agricultural land. Mr. Goschen in 1888 added to the duties on real estate, and deducted from the duties on personal estate, as paid into the Exchequer, so as to equalise the two (that is, as paid into the Exchequer). Then he made personal estate pay the amount formerly paid to the Exchequer to the local account. It was supposed that in this way personal property would contribute to local expenses. But this is illusory. So far (I888) personal property pays just the same as before-it is only the expenditure of it that varies-but real property (including agricultural estates) pays so much more. (The actual percentages are complicated.) Any relief afforded is given from the general funds of the State, and not from personal property only, and to these funds the landed interests contribute. All the latter gained was that some relief was given to rates which had increased on account of national or onerous services, so that, on the whole, the landed interests were worse off. By the Act of 1894 all pretence, except in name, was abandoned of personal property making contributions to local expenses.

The final outcome of the two Acts was simply that land now paid just as much as personal property (except for the instalment principle). Land, that is to say, paid so much more than before, relatively to personal property, and land, as such, received no relief, because the relief 
afforded to the local ratepayers was really for additional charges, and was in any case not sufficient. The Agricultural Rates Act did indeed benefit the landed interests, but it is purely illusory to say that the relief is given by personal property. It may be nominally assigned from that part of the estates duties levied on personal property, but if the rate is the same as on realty, it might just as well be paid out of the estate duties on realty itsclf.

Another point is the graduation of these duties, which falls very heavily on large estates, the estates which naturally or normally manage their agricultural land in the best way, and spend a large part of the rent on the estate.

The whole subject is complicated by legal, or in this case, accounting fictions, but the sum total of the legislation is that so far as imperial taxation is concerned, the owners of land are worse off than they were before; the addition has been real to their burdens, the relief given to local expenses has not been given at the special expense of personal property, or rather of its owners, but at that of the general tax-payer.

Up to this time (1894) land had been favoured in the matter of the death duties. It is curious that the additional burdens should have been inposed in the depth of agricultural depression.

See Final Report Local Taxation (1901) [Cd. 638] (pp. I I 2-I I 4). 


\title{
C H A P T E R III
}

\author{
LOCAL TAXES
}

IN the preceding chapter it was shown that there is no justification for the popular argument that so far as the national taxes are concerned the taxes that fall on agricultural land may be looked on as a kind of rent charge that equitably accrues to the State. It is, however, chiefly in reference to local rates that this theory of the hereditary burden is most often used, and it can only be met by a careful examination of the historical evidence. The history oflocal rates in England has been very fully and impartially treated by Dr. Cannan, and the history has been brought down 
to our own day in the papers submitted to the Commission by Sir Edward Hamilton and others, so clearly that any future writer may take the details for granted. My object is simply to show the bearing of the historical argument on the present situation.

"Almost all the money raised by English local taxation at present is raised either by means of the poor-rate, or by means of other rates, which, though they have names of their own, are, in reality, nothing but additions to the poor-rate." 1 The poorrate is based on the famous Act of 1601 (43 Eliz. c. 2), and the principle of that Act, as modified by actual practice and legal interpretation, is still the basis of the whole system.

The question, then, which seems to be of special importance in reference to the idea

1 Cannan, p. 2. See also First Report of Comm. on Local Taxation, p. 7 . 
of hereditary burden is: What was the underlying principle of this Act? Was the main object to tax "land-values," and to make the relief of the poor a "first charge" on the land?

A reference to the actual words of the Act gives no support to this idea. It says, first of all, that the money shall be raised by taxation of every inhabitant, and the words of the Act, as Dr. Cannan observes, say nothing whatever about the basis of taxation, and would, by themselves, cover an income tax, a poll tax, and many other taxes.

The real intention of the framers of the Act will probably be best discovered if we consider what was the practice up to that time as regards local rates. Long before this Act, various local wants had been met by some kind of local taxation.

In these early forms of local taxation we 
find two principles recognised. If we adopt modern phraseology, we may say that from the earliest times a distinction was drawn between rates for "beneficial" and for "onerous" services. If, for example, land was to be improved by a general system of drainage, each person whose property was benefited paid in proportion to the acreage, or to the value of his land. ${ }^{1}$

But rates were also imposed for nonbeneficial purposes, e.g., for repairing the town fortifications.

With regard to these charges, the accepted view in the fourteenth and fifteenth centuries was, that each inhabitant should pay according to his "ABILITy and substance." In actual history the term that constantly recurs is not "land-values," but the much more general expression, " ability and substance." 
The principle was fully recognised in the fourteenth century, which has only been rediscovered in the nineteenth, that it is always persons and never things that pay rates and taxes. But some visible sign was wanted of the ability and substance of people, and in this way the occupation of lands came to be the chief practical measure in the country, and the occupation of houses in the towns.

The next step is that people begin to think it is the lands and houses that are taxed, and not the persons. At first sight this might seem to be a case of a distinction without a difference, but the practical difference is soon of importance. Instead of the maxim of equity, that the same person ought not to be taxed twice for the same purpose-just as a man is not to be punished twice for the same offence-we have a maxim that the same thing ought not to be taxed twice 
over, which is as if when two people commit a murder only one should be hanged. This confusion between persons and things had begun before the Act of Elizabeth, but there seems little doubt that in modern phrase the poor-rate was intended to be a local income tax upon all the inhabitants of the parishes. The great difficulty as to the liability of nonresidents was met by including not only the inhabitants but the occupiers of lands and houses. This, no doubt, seemed to imply that it was the things - the lands and houses-and not the persons which were to be taxed. But it should be observed that the Act first applied to the "inhabitants" - and apparently the occupiers are brought in simply to cover the case of non-residents. ${ }^{1}$

${ }^{1}$ See First Report of the Commission on Local Taxation ( 1899 ) C $-9,14 x$. In this Report a history is given of the law affecting valuation. There was much controversy as to whether the taxation of inhabitants was to be extended to ability arising from all kinds of personal property or 
In time, however, the exception entirely ousted the principle. It became more and more the custom to measure ability solely by the value of the lands and houses occupied. And in the end, as a result of these confusions between persons and things, what had been intended to be a local income tax on all inhabitants, levied according to ability and substance, degenerated into a rate levied only on the occupiers of certain forms of property. At first it is probable that stock-in-trade was assessed just as in the case of the national taxes already noticed. In a few places, indeed, the system of rating in respect of

limited to the case of visible and tangible property easily cognisable. The courts were against the wider interpretation, and they laid down generally that non-residents could not be rated in respect of personal property in the parish. The distinction between residents and non-residents had been the point in dispute in Jeffrey's case before the Queen's Bench in $15^{89}$. It was decided that Jeffrey was liable for the repair of the Parish Church in respect of the lands occupied although he himself was non-resident. 
stock-in-trade continued down to the present century. ${ }^{1}$ And as is well known, the liability of stock-in-trade to be rated was decided in the Law Courts in 1840 , and was only annulled by a continued Act of Parliament.

Long before this-at the end of the seventeenth century and the beginning of the eighteenth, ${ }^{2}$ the drift of local and Parliamentary opinion was in favour of greater taxation of personal property. It was solely the practical difficulty of estimating the ability of people in terms of their other possessions which led to the customary exemption of personal property.

Another exemption from rating is of interest in connection with the present subject. We all know that in the income tax as at present levied, a farmer must pay on his profit, and the owner of the land on the rent which he receives from the farmer.

${ }^{1}$ Cannan, p. $86 . \quad{ }^{2}$ Cannan, p. 89. 
For income tax purposes, the profit of the farmer is still supposed to be indicated by a certain proportion of the rent (now onethird in England), and this mode of assessment is still optional. But, of course, the owner also pays on the full rental (less an allowance of one-eighth for upkeep, etc.) that is, he pays the national income tax; thus the owner pays a tax on the rent and the farmer a tax on the profit from the same land.

In the same way, the original poor-rate ought to have been imposed, both on the farmer according to his profit, and also on the landlord on account of his rent. Both were inhabitants, and both persons of substance.

The confusion, however, between things and persons led to the idea that if the farmer was taxed according to his rent, then the land, having already paid this 
tax, ought not to be taxed again, and in this way the landlord escaped.

In one sense, this mode of regarding the rate as levied directly on the rent of the land-as a thing in itself-may seem to support the theory of the "hereditary burden." But the central fact remains that it was on the occupier that the rate was imposed, and not on the owner; and taking a broad view of the original scope of the Act, it would seem that the rent was only to be taken as the test of the occupier's ability, as in the case of houses, and not that the occupier was to be considered as the agent by whom the landlord was to be reached. And it is worth noting that, as regards some exceptional rates that were imposed later on for various purposes in some places, it was sometimes provided that the amount of the rate should be deducted from the rent, and in one 
notable case any contract or custom notwithstanding. ${ }^{1} \quad$ But here the exception proves the rule.

When we consider the equities of the case, we must remember that as regards dwellinghouses also it was only the occupier who was rated, and in this case it is still more doubtful if the rate was transferred to any extent to the owner of the land. Another point of importance is that for many years, probably down nearly to the end of the eighteenth century, and in many instances much longer, agricultural land was let to yearly tenants at much less than the true competition rent. The rates being proportioned to the rents, so far the burden was less than on dwelling-houses, which were more under the influence of competition. And the landlord having already by custom given the tenant a continued

${ }^{1}$ Cannan, p. $3^{5}$. 
reduction from the competition standard, the tenant would not only nominally but really pay the rates.

The general conclusion thus seems to be that down to the end of the eighteenth century local rates are to be regarded as essentially of the nature of a local income tax. But in the first place, owing to a confusion between persons and things, the occupiers of lands and houses, and not the owners, came to be rated. So far, the landowner as such escaped, unless through economic forces, such as competition, some of the tax was transferred to him. ${ }^{1}$ That the landowner escaped may have been most inequitable, but at any rate, if for centuries he escaped, his land can hardly be said to have become subject to a hereditary burden.

And secondly, owing to the practical ${ }^{1}$ See below, chap. iv. 
difficulty of rating stock-in-trade, and other forms of personal property, it came to be the practice only to impose this local income tax, not on all the inhabitants, according to ability and substance, but only on the occupiers of lands and houses, and certain mines and woods, according to their annual rental.

With the progress of the country in wealth of various kinds, this local income tax assessed in this way became more and more unfair. Some important classes of incomes escaped altogether, and those that were rated were taxed with great inequality.

During the nineteenth century the defects and inequalities of this system have been remedied to some extent in different ways.

(I) In the first place, the meaning of rateable property has been somewhat extended. Other kinds of mines besides coal mines, other woods, etc., sporting 
rights, etc., have been included, and by the growth of the railway system, factories, and other kinds of fixed capital, the value of rateable property has been increased.

On the other hand, however, there has been no attempt to bring personal property under the rating system, and on the contrary, as we saw, legal recognition has been given to the actual custom that stock-in-trade and other personal property should not be liable.

(2) Secondly, the increase in the national duties imposed on the local authorities has been recognised by relief granted from the imperial Exchequer. In some cases, the services have been taken over and provided for by the central authorities. In others, funds have been provided to be expended under the management of the local authorities. In this latter case, at first grants-in-aid were given, the money being obtained by 
ordinary taxation; but later, under the high authority of Mr. Goschen, approved by Mr. Gladstone, certain national revenues were assigned to the local authorities.

We may defer for the present the consideration of the relative merits and defects of these two methods of grants-in-aid and assigned taxes, and fix the attention on the central fact that, for the last sixty years, it has been recognised that in some form or other, the local revenue obtained by rates should be supplemented by the proceeds of general taxation. In other words, it has been acknowledged that either the local authorities must be relieved of some of their functions, or else they must obtain assistance from the State to meet the expenses. The progress of the relief given from the national funds has been well described in the Memorandum of Sir Edward Hamilton.

In $1842-3$, in England and Wales, the total 
taxation raised for local purposes by local authorities (including what was received from tolls, dues, etc.) was over $£ 11,000,000$, and about a quarter of a million only was afforded by Parliament. In percentages in $1842-3$, for ninety-eight per cent. raised locally, only two per cent. was granted by Parliament. If we take account of the rates only, omitting the tolls, etc., the proportion of Parliamentary aid to the amount raised by the rates was still no more than three per cent. to ninety - seven per cent. By I89I-2, that is, in say fifty years, the proportions had changed to seventy-nine per cent., raised by rates to twenty-one per cent. granted by Parliament.

It is to be observed, however, that in spite of the increase in the proportion of the Parliamentary subventions, in another table it is shown that comparing the same two yearsI $84 \mathrm{I}$ and $\mathrm{I} 89 \mathrm{I}$ - the rate per $£$ had increased in 
the same fifty years from 2s. Iod. to 3 s. 7 d., that is, for the whole of England and Wales, and the rate has been rising since.

Two results stand out clearly in this general survey. The first result is that it has been recognised by successive governments for the last sixty years that the rates must be supplemented by subventions from taxation. And the second result is that, in spite of the increase in the amount of these subventions to local expenditure, the amount granted by Parliament has not been sufficient to check the growth of the rates imposed for onerous or national purposes.

As I shall try to show later on, in dealing with the question of the incidence of rates and taxes, the agricultural interest, as a whole, deserves to be still further relieved of the burden of local rates. Relatively to other industries during the last generation, agriculture has been depressed whilst they 
have prospered, and accordingly, as a whole, those engaged in agriculture relatively deserve more recognition as regards the distribution of what ought to be national burdens.

But, in the meantime, as insisted in the first chapter, agriculture can only expect relief in connection with a reform of the whole system. The Agricultural Rates Act has been renewed, it is true, with general approval, but the amount granted still remains the same as when fixed ten years ago. That is to say, the relief is fixed, whilst the need for relief increases.

I propose, then, to consider some of the objections that are made to the extension of the principle of Parliamentary aid, the principle itself having been for a long time well established.

Two main objections are raised - first, that the local authorities look on grants from 
the Exchequer, or the proceeds of assigned revenues, as in the nature of free gifts, which may be spent with the most reckless extravagance; and secondly, it is assumed, on the other hand, that if the ratepayers provide the money, they will also look to the efficiency of the expenditure. It seems to me that both of these time-honoured objections need qualification in the light of experience. In the first place, the tendency to extravagance in the expenditure of national funds may be held in check. The grants afforded by Parliament ought to be given only under proper limitations and conditions. Care should be taken that the central funds should be spent on national objects only, and the amounts assigned should be such as to require efficiency and economy in the administration. The Local Government Board, or other central authority, must exercise acontrolling influence over the administration; and above all, there 
must be a strict and rigid audit of the accounts.

The principle of the method of Parliamentary relief has now been admitted to such an extent that it would be absurd to say generally that local authorities cannot be trusted with public funds not raised out of the rates. They are already so trusted-and the extension of the trust is not a matter of principle, but of efficiency of administration. For the present, I am dealing only with the duties imposed on local authorities that may fairly be described as of a national character. Disputes, of course, will arise as to what is and is not to be included under this heading (e.g., what roads?), but there can be no dispute as to the reality of the distinction between onerous charges for national purposes and beneficial charges for purely local purposes. 
As a general principle of equity, national charges should be met from national funds, just as local benefits should be met from local funds. That is the equity of the case. But as stated in the first chapter, equity is not enough. Inter alia, we must consider economy. The objection, that I am now dealing with, to the extension of Parliamentary aid to local authorities, is one based on economy. It is implied that the money will be wasted. To this, one answer is that already noticed, namely, that this depends on the efficiency of the central control. But there is another answer. The ratepayers are also taxpayers. A farmer who pays income tax and various other taxes feels the burden just as much as the rates. If his rates can only be lessened by an increase in his taxes he will not be benefited. As a payer of taxes, he is as much interested in national 
economy as he is interested as a payer of rates in local economy. It is absurd to suppose that the same person considered as a ratepayer is a miser, but considered as a taxpayer, is a spendthrift. Of course, the real source of the confusion is this. The ratepayer hopes that if he is relieved in his rates he will not suffer in his taxes. And no doubt the very object of the relief is that, on the whole, the ratepayer should benefit. The object is to equalise taxes for national purposes. But the ratepayer will not escape altogether, because every ratepayer is also a taxpayer. If the ratepayers throughout the kingdom, as a body, get some relief, then the taxpayers, as a body, must get some additional burden. In the redistribution of burdens, the relief to the ratepayer is not all pure gain; he also will have to pay more taxes, and so far, he is interested in national economy. 
This leads me to notice the other main objection to Parliamentary subventions. It is supposed that to raise money by rates is a sure preventive of extravagance, because the ratepayers are spending their own money. This, however, is only true in the same general way as it is true of taxation. The members of Parliament, elected by the taxpayers, spend the proceeds of the taxes just as the members of the local bodies, elected by the ratepayers, spend the proceeds of the rates. When we look to experience, especially of recent years, it is much more easy to say that both the central Parliament and the local bodies-both the representatives of the taxpayers and those of the ratepayers-are extravagant, than to say which of the two is the more extravagant. Probably, on a comprehensive view, the Treasury is much less wasteful than corresponding local bodies. 
With regard to local extravagance with the proceeds of rates, the suggestion of Sir Robert Giffen seems reasonable, namely, that the control of expenditure should be, to some extent, in proportion to the amount contributed. The ratepayers should, on this view, be treated as if they were, so to speak, shareholders in a local company, and the voting powers should be proportioned to the shares held or the contributions made. This, however, is a point that arises rather in connection with the reform of the present system than as a question of relief to the ratepayer from the central funds.

Before leaving this question of comparative economy, it may be worth while to recall the truth that was emphasised by the old economists, in season and out of season, to such an extent that their children became so tired of hearing it that they shut their 
ears whenever it was uttered. Most people, indeed, seem to think that truth, like everything else, is subject to senile decay. The musty piece of practical wisdom that I wish for a moment to recall is, that the most effective way of securing economy in the expenditure of money is to see that people spend what is really their own money. We may dispute whether more money is wasted over education by the central or by the local authorities, but there is no doubt that one great check to extravagance was removed by the total abandonment of fees. When a man really levies rates on himself, and only on himself, and spends his rates on objects of his own choice, then you secure the greatest efficiency and economy. But this means that the more people do for themselves, and the less there is done for them, so much more value is got.for the money, and so on-so also of the moral values concerned. To resume the main 
argument, so far as local expenditure is for purely local benefit, it should, of course, be met out of local resources. This is obvious both on grounds of equity and economy.

Here, again, however, the present rating system seems inadequate, and in itself to call for reform. ${ }^{1}$ On this topic I will notice only one or two points bearing on agriculture. It seems reasonable that with due regard to existing contracts, rates should be divided between the owner and the occupier, as was recommended by the Duke of Richmond's Commission on the Depression of Agriculture. The reasons in favour of the proposal involve the question of incidence, and will be taken up later. The proportion of the division in different cases would be a matter for inquiry, but even a simple equal division, half and half, would be

1 "The number of rating authorities in England and Wales is over r,000."-Valuation Report, p. 29. 
more equitable than the present system. The adoption of this plan would conform to the idea that rates ought to be considered as a kind of local income tax. Both landlords and tenants should be rated on their incomes. If the rates are levied for purely beneficial, and not for onerous purposes, the distribution should be made to depend on the benefit to the occupier and owner respectively.

So far as the rates are for onerous purposes, the idea of a local income tax is dominant. And so far there seems to be no valid reason for supposing that the tenant's income is evidenced exactly by his rent. $^{1}$

1 Final Report of the Commission on Agricultural Depression (1898) C- 8,540, p. 30.- "Treating the whole of the published accounts as if they related to one business, it has been calculated that they show for the twenty years, 1875-1894, an average profit equal to 26.66 per cent. of the amount of rent and tithes, instead of 
Whether the idea of the local income tax could be extended to all incomes, even as in old times, to the hypothetical income from movables, is a wider question, but if it cannot, then it seems that ratepayers might be allowed some deduction from their contributions to the national taxation. Just as a deduction is made for insurance, so some deduction might be made in the national income tax on account of rates. This would directly throw part of the burden of the rates on the owners of personal property.

It may be pointed out also, that on the 43.75 per cent., the old basis of estimation for purposes of income tax. If this be only approximately correct, it follows that the farmers whose accounts have been furnished, have for the twenty years past received on an average only sixty per cent. of the sum which was in past days considered an ordinary and average profit."

Cf. also the remark in the report of Sir E. Hamilton and Sir George Murray (p. 143 of Final Report on Local Taxation): "The rateable value of agricultural land is a more misleading test of profit than in the case of any other rateable property." 
Continent various plans are actually adopted which have the effect of introducing an income tax for local purposes. It is not possible to do more than allude to this point. I am quite aware that there is high authority against the possibility of a local income tax. All that need be said is that if it is not possible, some other method must be adopted of making the owners of non-rateable property, and the receivers of incomes from other sources, contribute to all the local charges that do not directly benefit property only.

In any case, the agricultural interests ought to come in for a large measure of relief.

There can, however, be little doubt that whatever reforms are effected in local taxation, still more relief must be afforded from the imperial Exchequer. Accordingly, a few observations may be offered on the 
principles and methods of giving such aid.

After a careful study of the Report of the Royal Commission, and the separate reports of some of the commissioners, in my opinion the Report signed by Sir E. Hamilton and Sir G. Murray gives the best results when tested by economical principles. $^{1}$ They prefer the method of definite grants-in-aid to the assignment of particular taxes. They argue, and I think rightly, that so far as the national finances are concerned, it comes to precisely the same thing whether a sum is given from the general proceeds of taxation, or whether it is taken from some particular source. Of course, it would be different if the local authorities were permitted to make alterations in the taxes assigned, and to levy different taxes just as they levy

1 See Supplementary Note at the end of the chapter. 
different rates. But this was not intended, or at any rate, has not been done. The assigned taxes are not genuine local taxes, but simply the yield, or part of the yield, of certain national taxes granted to localities.

As regards the actual allocation, it is so complex, obscure, and full of anomalies that ${ }^{1}$ no general principles are discoverable.

The broad principle, however, on which aid ought to be given to local authorities, is that the central government is really answerable for certain services, although, for administrative means, it entrusts the carrying out to the local authorities. These authorities being, so to speak, merely agents for the central authority, should receive the cost from the national funds. In order that the national funds may not be used for purely local benefits,

1 Report, p. I I 4 . 
the money should be allotted for specific purposes, and there should be a general central control. Under the present system, there is a certain amount of "free balance" from the assigned taxes, which naturally leads to extravagance, or at any rate, is not used for purely national objects.

The Agricultural Rates Act was a reversion to the older method of a grant-in-aid, and in this view, the principle so far is sound, but the sums granted are given without proper central control, and without definite appropriation to specific services. ${ }^{1}$

Moreover, although this Act has redressed so far the inequalities between agriculture and trade in the same rating area, it has done nothing to rectify the disparity of rates in different areas. The Commissioners give some remarkable calculations illustrating the 
inequalities in the relief afforded to the different districts.

In dealing with the question of local rates and subventions from Parliament, I have considered only the leading ideas and principles. At the present time, however, it is precisely these principles that are really of the most practical importance. There can be no adequate relief to the agricultural interests without a reform of the whole system of local finance. The system, as it exists, is a conglomeration of legal contortions and historical accidents. The statesman who undertakes a real reform must grasp firmly the real economic conditions of the present time. I have appealed a good deal to history, but only with the view of clearing out of the way various popular fictions that obstruct all real reform. One of the most notable of these fictions is that rates are a "hereditary burden" on land. And by 
"land" is meant another fiction, namely, the unearned increment. The rates on agricultural land are actually at present a burden on agricultural industry. And so far from being a hereditary burden, the real intention in former periods was to favour agriculture. Rates on agricultural land are not of the nature of rent charges that belong to the people, but of the nature of income taxes that, by a series of accidents, are only imposed on some people and industries, and not on others. The practical question then is: Having regard to the present condition of agriculture, are those engaged in that industry able to bear the charges imposed on them and a probable increase of such charges? On this point the report of the last Commission on Agricultural Depression gives ample evidence. To say the least, relatively to other industries, agriculture has not prospered. It still remains, however, the 
greatest industry of the nation as a whole, and the most important on social and economic grounds.

If it can no longer claim special favour, at least it may claim freedom from exceptional burdens.

And finally, we must remember that taxes affect not only distribution but production. You may disguise the burdens on an industry so much that they cannot be measured, but that does not lessen the real weight. And other things being the same, to tax an industry is to depress it. Taxation may be a minor cause of agricultural depression as compared with the course of prices and foreign competition, but when profit is declining, and losses of capital are being incurred, taxation may, in many cases, be the proverbial last straw; and in any reorganisation of the system of local finance, agriculture ought to receive favourable consideration. 
The most difficult question of all-the real incidence of the rates and taxes-is taken up in the next chapter.

Supplementary Note on the Special Report by Sik Edward Hamilton and Sir George Murray

\section{Idea of Hereditary Burden}

The persistency of this idea is shown by the argument of these Commissioners on p. 127 (Final Report).

They argue that for onerous purposes, if it were possible, the rates should only be levied on residential property as being apparently a fair evidence of income. But this exemption of other property (including, I suppose, land used for agriculture) is objected to principally because it would "exempt from rating a very large amount of property all over the country which has for centuries contributed to local expenditure, and has passed from hand to hand, subject to that liability; and though we feel that the present system is open to serious criticism, from an equitable point of view, yet it seems that the entire exemption from local taxation of any property at present brought into charge would be inadmissible."

This seems to be the hereditary burden theory in its simplest form. And yet the authors of this Memorandum have shown most clearly that it is not things but persons that are taxed. In the concrete, if you impose taxes on agricultural land, you tax the persons engaged in agriculture, and the tax comes out of their profits. If they did not work the land, it would give no tax. 


\section{The Economy of Rates}

Another persistent idea may be illustrated from the same writers. They accept the notion that a local income tax is impossible. They accept also the idea that local profits cannot be taxed. That also is impossible. And yet these same Commissioners show most clearly that a rate for onerous purposes is really an income tax levied on all kinds of incomes, because the possessors of these incomes are, for the most part, occupiers of dwellings.

A rate is an income tax, so far as the ratepayers are concerned; but it is partial and inequitable, because some incomes escape altogether and some partially.

We might not be able to tax all profits in the most equitable way, but we might, at least, tax them to some extent, and, so far, that would relieve the other ratepayers. And we might supplement the dwelling-house test, by other local signs and evidences.

The legal fictions regarding the rating of railways are instructive (p. 126). The economic or political idea was to rate railways according to their profits; but the lawyers came in, and a mass of cases have given rise to all sorts of rules for the discovery of the rateable property used by the railways. In this case, at least, it would have been infinitely simpler to levy the rates on the dividends, but the fiction of real property only being rateable prevented it.

It is stated (p. I24) that if the whole of onerous expenditure could be met from national funds it should be done, but it cannot. The reason assigned is that those 
who spend the money must directly, or rather, as they say, nominally contribute. But the whole of the expenditure of the Army and Navy and the Civil Service is managed without this idea. The proper test is which management (local or imperial) is the most efficient or economical. We do not secure these qualities simply by saddling the rates, especially if it is done by "precepts."

The same idea is at the basis of the half-and-half rule. They think in no case should more than half the onerous charge be given to the local authorities (pp. 131, 144).

Similarly, the proposal to fix the grant for ten years is founded on this idea of enforcing economy, and it is assumed that if left to the rates it must be econonical.

And yet the same authors have put the essence of the matter in a sentence.

It is a question, they say, not of real property against personal, but of national services against local services, and the problem is how the onerous expenditure on these national services which are locally administered can most equitably be met (p. 144). "If the assistance, already considerable, were made to cover the entire expenditure of an onerous character locally, the problem of taxation for local purfoses would be solved" (p. 124). Each locality would then provide its own benefits at its own cost and risk.

The point is, we must always compare the defects of the present system with the possible defects of a new system. Every tax has its faults.

The gross inequality of the present system of rating is 
well brought out in the principal Final Report (p. 55) as regards machinery. See also (p. 46) the whole chapter on exemptions.

The Memorandum prepared by Mr. Rew (Appendix to the "Minutes of Evidence," vol. i. (1898), p. 337, sq.), gives examples of the unfair rating of farms compared with other property. 


\section{CHAPTER IV}

THE INCIDENCE OF RATES AND TAXES AS AFFECTING THE AGRICULTURAL INTERESTS

Some of the most difficult questions in taxation arise in regard to the real incidence and the ulterior effects. Unfortunately, also, they are of fundamental importance. If they are evaded, the whole superstructure of reform may be faulty, and the new system may be worse than the old. This is well expressed in the Memorandum by Sir Edward Hamilton, which forms the introduction to the volume of the answers - on the classification and incidence of imperial and local taxes given by the leading experts on the subject to a 
series of questions propounded by the Commissioners. "We should first endeavour," he says, "to probe to the utmost the difficult and abstruse question of the true incidence of rates and taxes, and especially of rates. It is the solution of that problem (so far as any solution is practicable) by which alone we can properly answer the terms of reference made to us." A little later on, he also says, in reference to any proposals for the redress of any inequalities that are discovered: "In attempting to solve these difficult problems, we must take care not to redress any present inequalities by creating fresh inequalities; and if we propose any alterations in our existing financial system, we shall do well to bear in mind that there is great force in the old saying that 'an old tax is no tax.'" The truth is, that if it is difficult to 
estimate the incidence of old taxes in which, at any rate, there is some reference possible to the result of experience, it is still more difficult to estimate the effects of a new system. Even as regards the old taxes, however, it must not be supposed that we can find a ready answer by consulting the results of the past. The effects of taxes are inextricably blended with other things.

If we take the reports of the last two commissions on agricultural depression, we find that the main causes are, in the first period under review, bad seasons, and in the second, low prices. The precise influence of rates and taxes, even if considerable, would be. overshadowed by these greater causes. Even if we were to compare districts in which rates are relatively high and low, it is unlikely that we could assign any precise influence to the difference, unless 
it were very extreme and the circumstances peculiar. We are then obliged, in the first place, to attack the problem by what is called the deductive method. We must try to isolate the principal forces involved, and discover their effects in the absence of what are called disturbing causes. When we have discovered the resultant tendency of these forces under the assumed simple conditions, we can consider how far they are modified in practice by the interference of the disturbing causes.

You will observe that as regards any particular problem, the application of this method is not complete until we have taken account of all the experience available. The economic theorist does no more than provide the man of affairs with lines of inquiry, and without guiding clues of some kind, the facts cannot be utilised at all. 
In this part of the subject I shall deal principally with the incidence of rates on agricultural land. In its simplest form a rate is a tax imposed on the net rental of land. There are three possible persons who may ultimately or really pay the tax, namely, the landlord, the tenant, and the consumer of the produce. It is easy to show that under present conditions, the consumer will bear very little, if any, of the burden. He could only be affected by a rise in prices, and prices are mainly dominated by foreign competition. And even if the country were isolated, and the rate were imposed strictly on the economic rent pure and simple, it might also be shown that the consumer would not bear any part of the burden. But in this case, as will appear later, if the tax is not on the pure economic rent, but on the gross rental, the consumer might bear part at least of the 
burden. Practically, however, in England at present the consumer is not affected. The question, then, of most interest and difficulty for the present purpose, is the incidence as between the farmer and the landlord. To begin with, in theory and under the simple conditions assumed, it makes no difference whether the occupier or the owner is made to pay in the first instance: we are concerned with the ultimate or real incidence. If the farmer pays the rate, but by way of compensation pays so much less rent than he would do if he were not responsible for the rate, the rate, of course, comes out of the rent. And this, I may say, is the usually accepted theory of the incidence of rates. It is important to see the principles on which the theory rests.

In the first place, it is assumed that under the influence of competition, the farmer will only offer so much rent as will leave him on 
the average, and in the ordinary and expected course of things, a fair or ordinary profit. What constitutes a fair or ordinary profit will, of course, depend on circumstances, and inter alia, on the chance of profit in other employments or investments. But it may be said that, at any rate, something more is expected than a bare return in the way of interest; something more than could be obtained without trouble or risk by investing the same capital in some first-class security. What the actual rate of ordinary agricultural profit may be, is not of so much importance as the fact that under competition it ought to be uniform throughout; that is, for equal masses of capital and equal abilities. If in one county or district the rates were high relatively to its neighbour, the landowner could only secure tenants by paying the differential part of the rates. And in both districts, it is argued, the 
landlord must pay any part of the rate which if paid by the farmer would lower his profit below the normal. On this view, you will observe that the profit of the farmer is looked on as a first charge on the proceeds of his cultivation. The rent is a surplus, which being lopped off, simply equalises the profits of farmers in general. The rate or the tax is again only a proportional part of this rent. It is a fraction of the surplus, and leaves the farmer unaffected. This is the simple economic theory, and if the conditions assumed hold good, so also does the theory.

But in practice the theory is applied by reformers, who are not engaged in agriculture, regardless of its strict meaning and of the conditions and assumptions. The fierce discussion on the Agricultural Rates Act on its introduction and first renewal is a good illustration. The relief was said to be simply a dole to the landowners. 
Almost the only qualification admitted of this idea of a dole to landlords was that if new rates had been imposed during the currency of a lease, rates that were not contemplated when the rent was agreed to, for the time being the tenant would pay the rates, and would, of course, receive the relief. In this case, however, it was also supposed that if the tenant were relieved of any part of the rates, on the conclusion of his lease his rent would be raised in the same proportion.

In the last debate in the House of Commons this session, it was asserted over and over again that the landlords had not benefited, and the most that could be said on the other side was that but for the relief their rents would have fallen still more, that they must themselves have made reductions to the farmer, and that they had so far benefited. And the popular implication was that any 
benefit to the landowners was a benefit to unearned increment at the expense of labour.

It is not the fault of the economists if their theories are used not as they should be, as guiding clues in the investigation of facts, but as a substitute for any inquiry. The economist always admits that an allowance must be made for "friction," and economic friction includes everything that is of practical importance.

How far, then, do present conditions conform to the conditions of the theory? There ought not to be much trouble in ascertaining the most important facts owing to the prolonged labours of successive commissions on agriculture and taxes.

Consider first the case of rent. The theory just examined refers to pure economic rent; that is, the surplus that is due to differential natural advantages. That is the strict meaning. And here one of the conclusions 
of the last commission on agriculture, which was quoted before ${ }^{1}$ in another connection, is of importance. Over a considerable part of England the economic rent, in the strict sense, has vanished. The rent of land used for agriculture is, to a great extent, simply profit on the capital sunk in the land by the owner, or his predecessors in title. If allowance is made for all this expenditure in the past and the necessary renewal, the pure economic rent becomes an insignificant factor. Even J. S. Mill, who is the reputed father of the unearned increment, stated that most of the valuable qualities of agricultural land were due to labour, and in that connection, pointed out the importance of the security afforded by the institution of private property, especially in effecting the more permanent improvements.

In fact, the greater part of the present ${ }^{1}$ Chapter ii. 
agricultural rental is a kind of profit on the investment of capital in the past. Profit, again, is complex, and the different elements in gross profit ought to be taken separately, especially if we are considering the effects of taxes.

Some of the improvements effected in land are of such a character that they become in time part and parcel of the land itself. Such are the results of the clearing of land and of the introduction of arterial drainage and permanent roads. Even in these cases, however, the benefit of the improvements cannot be retained unless there is a more or less continued application of capital and labour. Take, for example, the drainage and roads of the fens. And in any case, in any kind of agricultural land, a considerable part of the rental must be spent in renewals or making good depreciation. Here, again, the report of the last commission on the 
depression of agriculture is most instructive. ${ }^{1}$ These tables show that of the rental agreed to about ninety per cent. was actually received. That, by the way, is a reduction of $2 \mathrm{~s}$. in the $£$. Over the whole of Great Britain it is estimated that nearly forty per cent. of the rent actually received is disbursed in outgoings, including public charges and the expenditure necessary for the upkeep of the property. Under these public charges no allowance is made for income tax, or any of the ordinary national taxes. Besides this, as regards England and Wales, it is reckoned that the capital expenditure on improvements amounts to one-fifth of the net rent received by the landowner. Observe, this is taking the land as a going concern. The estimates refer to what is being done with the rental that is actually being received. No account is made of the

${ }^{1}$ See the tables on pp. 27,28 . 
effects of the permanent improvements effected by the investments of the pastthey are reckoned simply as part of the land.

Another sentence from the Report may also well be quoted : "It is obvious that anything in the nature of a fixed or permanent charge becomes more onerous as the sum out of which it is paid diminishes in amount. While some of the outgoings which landlords have to bear, such as tithe rent charge and land tax, are capable of some readjustment, they have not generally been reduced in proportion to the net value of the land; but charges for drainage and repairs are not reduced, however much rent may fall. Leaving out of sight family charges and mortgage interest, which press heavily on so many owners of landed estates, there are very heavy outgoings that cannot be reduced in proportion to the fall in rents." 1 
The natural effect of this fall in net rental is seen in the changes made in the uses of land. Some land has gone out of cultivation, and other land is much less highly cultivated. Capital that does not yield a profit, or in some cases does not provide against depreciation, is not renewed.

We see what a difference is made in the popular view of incidence if we pay attention to the nature of rent as actually received and expended. A large part is quite different from the economic rent of pure theory. And it follows that a tax or a rate that falls on this part must have the same effect as a tax on any similar form of industrial profit.

But at this point it must be observed that the popular theory of incidence will no longer hold good in the simple form as at first stated. That theory only applies to the pure economic rent, or at most in addition, to the so-called quasi-rent on the fixed 
capital already sunk in the land, which cannot be withdrawn, and which must be kept up to secure the payment of the rest of the rent. In brief, it does not apply to that part of rent which is properly on the same footing as farmers' profits. So far, we ought to say that unless the owner receives the ordinary rate that may be fairly expected, he will not employ his capital on the land. But it is clear that the owner of the land is not so favourably placed as the ordinary farmer.

As just observed, in order to get any rent at all, there must be some employment of landlords' capital. And so long as there is any true surplus, it may pay to lose the profit on part of the capital expended in the upkeep.

We arrive then at this position. The incidence of rates as between landlord and tenant depends largely on the relative 
mobility of the respective capitals; it is a contest between two sorts of profits, or an adjustment of two sorts of losses.

This leads to another qualification of the ordinary theory. That theory expresses a tendency that is true only in the long run and in the absence of disturbing causes. It really assumes a stationary set of conditions, such as a normal rate of profit in agriculture, as compared with other industries. Owing to the agreeableness of the employment and the economies in some ordinary expenses of the household, the rate to be expected in agriculture ought to be put much lower than the rate in other industries. For the sake of clearness, we will suppose that if in ordinary trade capital yields ten per cent., in agriculture it will only yield five or six, if ordinary expectations are realised. Still, whatever the difference may be, it is supposed that 
this ordinary rate over a term of years will be obtained.

Here again, however, we have another pure theory: the theory, namely, of the tendency of profits to an equality, after allowing for certain natural and permanent causes of difference. This theory itself is only true with important qualifications and assumptions. It expresses, no doubt, the operation of real causes of the first magnitude. But again, allowance must be made for friction and for changing conditions.

It was pointed out at the beginning of this examination of incidence, that, owing to the influence of foreign competition, rates and taxes on agriculture could not be transferred to the consumer in higher prices. But we must now observe that this is the usual mode in which the tendency to equality of profits is supposed 
to operate. If any branch of industry is getting below the normal rates, production is checked until the reduction of supply raises prices. Suppose, however, that prices are practically determined independently of the short supply in any one country. Under these conditions, the result must be that the industry will gradually decline; only the most profitable branches will be continued; the capital will be renewed to a less extent; and on the whole, that industry will, relatively to others, have a low rate of profit.

Owing to the large amount of fixed capital in agriculture, including the improvements fixed in the land, it will pay for a long time to work the land in some way, so as at any rate to avoid a total loss. Landlords and farmers cannot remove their capital to more flourishing industries. Besides their fixed capital, there is also 
their fixed skill. And so long as any surplus at all remains in the form of gross rent, the land will be cultivated, although it does not give ordinary interest on all the capital sunk in it.

Let us now consider the influence of declining profit on the distribution of the burden of taxes as between the landlord and tenant. And let us suppose that there is some increase of rates during the currency of a lease. At the end of it, the tenant will, no doubt, try to obtain a corresponding reduction of rent. With declining profit and competition for tenants, rather than by tenants, the power in bargaining is on the side of the tenant, and he is likely to obtain the reduction. In precisely the same way, if the tenant has suffered by bad seasons or by low prices, he will probably obtain not only an ultimate reduction but some partial remissions. 
And in confirmation of the general argument, it may be said that according to the report of the Commission the landowners have suffered most severely. The loss caused by rates and taxes is, of course, relatively small compared with the influence of prices. The point is, that the effect, so far as it does operate, is the same. A large part of the loss is ultimately thrown on the rent.

And this is natural from the very idea of rent. Rent is a surplus, and economically is only entitled to the second preference in the distribution. This is true, not only of the true economic rent for the natural qualities (which has largely disappeared), but of the profit rent for the landlords' capital, which has become part and parcel of the land.

Again, it may be observed that the rates are supposed to be levied only on the net rental or surplus (after allowing for insur- 
ance, upkeep, etc.). ${ }^{1}$ So that the burden should be reduced as the rent or surplus falls.

But as already shown, this supposed net rent is to a great extent only obtainable, when agricultural profit is declining, on condition that the owner of the land continues to put money into it. The loss in rental again is only part of the loss of the landlord; and as the figures show, in spite of the depression and the fall in rents, the landlords of England spend a large part of their rents actually on the land itself. So far, then, as the rates fall on rent, there is so much less to spend on the land, and so much less ability to relieve the tenants in any temporary emergency.

In this way, it is seen that the tenant does not escape altogether, even if he obtains a reduction of rent. With falling rents the

${ }^{1}$ See Valuation Report, p. I 7 . 
owner cannot do so much for the estate. But the real loss to the tenant is only fully seen-when we take account of the custom by which the rates are payable by the tenant. During the lease, it is plain that the first loss falls on him. Even if there is no increase of rates, still, if the true rent is falling, the burden is increasing. And if the rates increase, it is still worse.

In theory, no doubt it makes no difference who pays the rates in the first place, landlord or tenant, because the ultimate adjustment of the rent will take account of the rates. But ultimate relief is one thing, and present relief quite another. If the true rent (that is, the real surplus) is falling year after year, though adjustments are made, they may always be a little too late. And in this way, there is a continuous drain on the tenants.

We now see why the Agricultural Rates 
Act may well have been a relief to the tenants; and the evidence seems to show that in no case had rents been raised in consequence. In yet another way the burden of rates may be seen to fall, partly at any rate, on the tenants. The farmer, it is said, if he cannot get the rates practically deducted from the rent in one place, will go to some other place. So far as it operates, this mobility of farmers' capital no doubt mitigates the inequalities that would otherwise result. And between different localities the rents tend to be so adjusted that rates and rents together put the tenants on about the same footing. That is, of course, again only a tendency that is liable to be counteracted; but even supposing it operates to the full extent, you will observe it only applies to the equalisation of differences. So far as the burden is the same, there is no such mode 
of relief. In this way, part of the general burden may remain on the tenants.

It is, in reality, a kind of additional income tax on their profits.

Now, no one would say that the tenant can get his income tax out of his rent. If the income tax were raised to $2 \mathrm{~s}$., that would make no difference to the bargain for rent. And so far as the rates correspond to a kind of income tax, they cannot be transferred.

On this point the comparison with urban rates is instructive. There the usually received theory is, that in the normal case, rates really fall on the occupier. They are regarded as a kind of local income tax. The idea is, that rental gives a rough measure of ability.

J. S. Mill says that in most cases nearly all the tax on dwelling-houses falls on the occupier. This is, of course, taking the case 
of ordinary dwelling-houses. In the case of shops, part may be transferred to the consumer of the goods and part to the ground landlord, but part, at any rate, will act like an additional income tax. ${ }^{1}$ Similarly, rates on railways, canals, gasworks, and waterworks are, in the main, taxes on the profits of the shareholders ; that is, they are of the nature of an income tax.

The idea that rates on agricultural land do not affect the occupier (except when changed during his lease) rests on the idea that the rent of land is a true economic rent-a pure surplus, arising solely from differential natural advantages. As soon as the central fact is realised that the greater part of gross rental is really profit, and profit at a very low rate, this simple method of regarding the subject must be abandoned. The rates and taxes on agriculture fall for

'Blunden, p. 6o, et infra. 
the most part on the profits of agriculture. As between landlord and tenant, the landlord may bear most of the burden, so far as the necessary readjustments are being continu. ously made, and so far as the rates are differential. But the tenant practically suffers, partly because the readjustment is not continuous, and partly because a part at least of the rates is really an income tax on his profits. The exact distribution between the two interests (landlord and tenant) will vary in different cases, and according to changes in the conditions.

In conclusion, some attention must be given to the more general effects. There can be no doubt that, taking landowners and tenants together, rates must be paid out of the profits of agricultural industry as a whole.

From this point of view, the distinction between onerous and beneficial rates is important. 
But in the course of history, and especially in recent years, whilst the total burden of rates has increased, the proportion of onerous rates has also increased. That is to say, agriculture has more to bear, and in proportion, gets less in return.

It is true that in towns and cities the rates have increased to a still greater extent, but then there also the benefits conferred have been greater. A large part is payment for services rendered. Again, on the whole, the towns and cities have been increasing in wealth and population, and in the power to bear additional burdens. There are, no doubt, exceptions, and no doubt also there has been a good deal of extravagance and waste, and there are inequalities in the burdens for national purposes as between different urban localities. But taking a broad survey of the last fifty years in particular, town industries have prospered, whilst 
agriculture, the main industry of the country, has certainly not advanced in anything like the same extent, and has probably retrograded, taking capital and profits as the test. It is not necessary to take the exaggerated estimates of Mr. Palgrave to the foot of the last figure. A good deal of the loss shown in his figures may be due to a difference in the mode of measurement.

You can make land fall in capital value fifty per cent. by reducing the number of years' purchase fifty per cent., the rental being practically the same. And similarly, the estimates of the losses of farmers' capital may be to some extent altered simply by the mode of valuation adopted of the very same things. Still, after making all allowances, there is no doubt that, relatively, agriculture has been much depressed. ${ }^{1}$

1 See Report on Agricultural Depression, p. 30. 


\section{GENERAL CONCLUSION}

As the argument has been necessarily complex and difficult, owing to the nature of the subject, it may be well, in conclusion, to indicate briefly, if dogmatically, the main results.

The first position in the argument is that the case of the taxation of agriculture can only be treated in connection with the whole tax-system of the nation, both imperial and local.

Next, in any proposals for reform, account must be taken of present conditions and customs and of their historical origins. One very popular view is that the greater part of the taxation falling on land ought to be considered as a kind of rent charge in favour 
of the public. This opinion is popularly associated with the idea that historically all land belonged to the Crown as representing the people. This popular view was shown to be erroneous both in general and in particular. Any definite rights to any part of the rental of land (such as certain feudal charges) were abandoned centuries ago. Then, again, as regards the popular idea that by ancient custom taxes on land may be regarded as a hereditary burden, it was shown that the intention had always been to tax other forms of wealth equally with land, and that, as far as was practicable, the intention had been carried out. With regard to the national taxes, land had down to quite recent times been favoured, as compared with other forms of property, and agriculture as compared with other industries. This favour had been justified, partly on the ground that agriculture was of vital importance to the nation, 
and partly on the ground that land bore an undue share of local burdens.

Next, it was shown that even as regards local taxation, originally other forms of income were supposed to be taxed equally with the rental from land; that is, for any onerous charge of which poor relief is typical. It is sometimes said that the relief of the poor is a first charge on land; it would be equally true to say that it is a first charge on all property. It was never intended that land should bear special differential charges for onerous purposes whilst other property escaped. Rates on houses and other forms of property that came to be rated were in their origin of the nature of local income taxes.

During the last half century, there has been a continuous and progressive increase of local burdens for national charges. In particular, burdens on the agricultural 
interest have increased without any corresponding special benefit to agriculture. At the same time, especially of recent years, agriculture has become less able to bear taxation. The popular idea that there is in land-values a large unearned increment available is, as applied to agricultural land, the reverse of the truth. On the whole, the rental of land is kept up because a large part of it is expended on the land. A tax, even if it falls on rent, tends to depress agriculture.

With regard to remedies, what is required is a complete reorganisation of the whole system of local finance; and in this reform, agriculture should receive equitable treatment, having regard to actual conditions, and not to fictions, whether legal, historical or economic.

THE END 


\section{SOCIAL SCIENCE SERIES. SCARLET CLOTH, EACH 2s. lid.}

1. Work and Wages.

Prof. J. E. ThOROLD Rogers. "Nothing that Professor Rogers writes can fail to be of interest to thoughtful people."-A thenaum.

2. Civilisation: its Cause and Cure.

EDWARD CARPENTER. "No passing piece of polemics, but a permanent possession."-Scottish Review.

3. Quintessence of Socialism.

Dr. SCHÄFFLE.

"Precisely the manual needed. Briel, lucid, fair and wise."-British Weekll.

4. Darwinism and Politics. New Edition, with two additional Essays on Human Evolution.

"One of the most suggestive books we have met with."-Literary World.

5. Religion of Socialism.

6. Ethics of Socialism.

E. BELFORT BAX. Review.

7 The Drink Question.

"Plenty of interesting matter for reflection."-Graphic.

8. Promotion of General Happiness.

"A reasoned account of the most advanced and most enlightened utilitarian doctrit.e in a clear and readable form."-Scotsman.

9. England's Ideal, \&c.

EDWARD CARPENTER.

"The literary power is unmistakable, their freshness of style, their humour, and their enthusiasm." - Pall Mall Gazette.

10. Socialism in England.

SIDNEY WebB, LL.B. "The best general view of the subject from the modern Socialist side."-Athenaum.

11. Prince Bismarck and State Socialism.

W. H. DAWSON.

"A succinct, well-digested review of German social and economic legislation since $1870 . "$-Saturday Review.

12. Godwin's Political Justice (On Property). Edited by H. S. SALT.

"Shows Godwin at his best; with an interesting and informing introduction."Glasgow Herald.

13. The Story of the French Revolution.

"A trustworthy outline."-Scotsman.

14. The Co-Operative Commonwealth.

E. Belfort BAX. Reviero.

15. Essays and Addresses.

"Ought to be in the hands of every student of the Nineteenth Century spirit."Echo.

"No one can complain of not being able to understand what Mr. Bosanquet means."-Pall Mall Gazette.

16. Charity Organisation.

C. S. LocH, Secretary to Charity Organisation

"A perfect little manual."-A thenoum.

Society.

"Deserves a wide circulation."-Scotsman.

17. Thoreau's Anti-Slayery and Reform Papers.

"An interesting collection of essays."-Literary World.

18. Self-Help a Hundred Years Ágo.

Edited by H. S. SALT. "Will be studied with much benefit by all
of the condition of the poor."-Morning Post.

19. The New York State Reformatory at Elmira. ALEXANDER WINTER. With Preface by HAvelOCK Elis.

"A valuable contribution to the :iterature of penology."-Black and White.

20. Common Sense about Women.

T. W. Higginson.

"An admirable collection of papers, advocating in the most liberal spirit the emancipation of women."-Woman's Herald.

21. The Unearned Increment.

"A concise but comprehensive volume."-Echo.

22. Our Destiny.

W. H. DAWSON.

"A very vigorous little book and religion."-Daily Chronicle. 


\section{SOCIAL SCIENCE SERIES-(Continued).}

\section{The Working-Class Movement in Amerlca.}

Dr. EDWARD and E. MARX AVKI.ING.

"Will give a good idea of the con"ition of the working classes in America, and of the various organisations which they have formed."-Scots Leader.

24. Luxury.

Prof. EMILE DE LAVFi.f.YF.

"An eloquent plea on moral and economical grounds for simplizity of life."A cademy.

25 The Land and the Labourers.

Rev. C. W. Situbas, M.A.

"This admirab'e book should te circulated in every village in the counery." Manchester Guardian.

26. The Evolution of Property.

PAUt. I.AFARGUF.

"Will prove interestirg and profitable to all students of economic history."Scotsman.

27. Crime and its Causes.

W. DOUgl.as MORRISON. "Can hardly fail to suggest to all readers several new and pregnant reflections on the subject."-Antr-Jacobin.

28. Principles of State Interference.

D. G. Ritchis, M.A.

"An interesting contribution to the controversy on the functions of the State."Glasgotu Heralu.

29. German Socialism and F. Lassalle.

W. H. DAWSON.

"As a biographical history of German Socialistic movements during this century it may be accepted as complete." - British Weekly.

30. The Purse and the Conscience. H. M. Trompsos, B. A. (Cantab.). "Shows ccmmon sense and fairness in his arguments."-Scotsmam.

31. Origin of Property in Land. FUSTEL, IDE CoUl,ANGFs. Edited, with an Introductory Chapter on the English Manor, by Prof. W. J. Asit.F., M.A. "His views are clearly stated, and are worth reading." - Saturday Revieze.

32. The English Repubilc. W. J. I.INTON. Edited by KINETON PARKES. "Characterised by" that vigorous intellectuality which has marked his long life of literary and artistic activity."-Glasgose Herald.

33. The Co-Operatlve Movement.

BEATRICE POTTER

"Without doubt the ablest and most philosophical analysis of the Co-Operative Movement which has yet been produced." - Speaker.

34. Neighbourhood Cullds.

Dr. Stanton CoIt.

"A most suggestive little book to any one interested in the social question."P'all Mall Gazette.

35. Modern Humanists. criticisms bear the mark of much acumen." - Times.

36. Outlooks from the New Standpoint.

J. M. RORERTSON.

E. BEI.FORT BAX.

"Mr. Bax is a very acute and accomplished student of history and economics." -Daily Chronicle.

37. Distributing Co-Operative Societles. Dr. Luigi Pizzamigi.io. Fdited by F. J. SNELI.

"Dr. Pizzamiglio has gathered together and grouped a wide array of facts and statistics, and they speak for themselves."-Speaker.

38. Collectivism and Socialism. By A. NACQUET. Fdited by W. HFAFORD. "An admirable criticism by a well-known French politician of the New Sociali*m of Marx and Lassalle."-Daily Chronicle.

39. The London Programme.

"Brimful of excellent ideas."-Anti-Jacobin.

40. The Modern State. PAUl. I,ERoy Beaut.IF.t.

SIDNEY WEBB, LL. B.

"A most interesting book; well worth a place in the library of every social inquirer." - N. B. Economist.

41. The Condition of Labour.

"Written with striking ability and sure attactattention " NENRY GEORGF.

42. The Revolutionary Spirit preceding the French Revolution.

FELIX RocQUAIN. With a Preface by Professor HUXIEY.

"The student of the French Revolution will find in it an excellent introduction to the study of that catastrophe." -Scotsman.

43. The Student's Marx.

EDward AveliNg, D.Sc. "One of the most practically useful of any in the Series."-Glasgow Hcrald.

44. A Short History of Parliament.

B. C. Skotrowe, M.A. (Oxon.).

"Deals very carefully and completely with this side of constitutional history."Spectator. 


\section{SOCIAL SCIENCE SERIES-(Continued).}

45. Poverty: Its Genesis and Exodus.

J. G. GODARD.

"He states the problems with great force and clearness."-N. B. Economist.

46. The Trade Policy of Imperial Federation.

MAURICE H. HeRvey.

"An interesting contribution to the discussion."-Publishers' Circular.

47. The Dawn of Radicalism.

J. BOWLES DALY, LL.D.

"Forms an admirable picture of an epoch more pregnant, perhaps, with political instruction than any other in the world's history."-Daily Telegraph.

48. The Destitute Alien in Great Britain. ARnold White; Montague CrackanthorPe, Q.C. ; W. A. M'Arthur, M.P.; W. H. Wilkins, \&c.

"Much valuable information concerning a burning question of the day."-Times.

49. Illegitimacy and the Influence of Seasons on Conduct.

Albert Leffingwell, M.D.

"We hare not often seen a work based on statistics which is more continuously interesting."-Westminster Review.

50 . Commercial Crises of the Nineteenth Century.

H. M. HYNDMAN.

"One of the best and most permanently useful volumes of the Series."-Literary" Opinion.

51. The State and Pensions in Old Age. J. A SPENDER and ARTHUR ACLAND, M.P. "A careful and cautious examination of the question."-Times.

52. The Fallacy of Saving.

"A plea for the roHN M. ROBERTSON.

53. The Irish Peasant.

JOHN M. ROBER'
Mystem."-Speaker.

"A real contribution to the Irish Problem by a close, patient and dispassionate investigator."-Daily Chronicle.

54. The Effects of Machinery on Wages.

"Ably reasoned, clearly stated, impartially written."-Literary World.

55. The Social Horizon.

"A really admirable little book, bright, clear, and unconventional."-Daily" Chronicle.

56. Socialism, Utopian and Scientific.

"The body of the book is still fresh and striking."-Daily Chronicle.

57. Land Nationalisation.

FREDERICK ENGELS.

"The most instructive and convincing of the popular wort National Reformer.

58. The Ethic of Usury and Interest.

"The work is marked by genuine ability."-North British A griculturalist.

59. The Emancipation of Women.

A. R. WALLACE.

"By far the most comprehensive, luminous, and penetrating work on this question that I have yet met with." -Extract from Mr. GLADsTone's Preface.

60. The Eight Hours' Question.

JOHN M. ROBERTSON. "A very cogent and sustained argument on what is at present the unpopular side."-Times.

61. Drunkenness.

GEORGE R. WiLson, M.B.

"Well written, carefully reasoned, free from cant, and full of sound sense."National Observer.

62 The New Reformation.

RAMSDEN BALMFORTH.

"A striking presentation of the nascent religion, how best to realize the personal and social ideal."-Westminster Review.

63. The Agricultural Labourer.

T. E. KEBBEL.

"A short summary of his position, with appendices on wages, education, allotments, etc., etc."

64. Ferdinand Lassalle as a Social Reformer.

E. Bernstein. "A worthy addition to the Social Science Series."-North British Economist.

65. England's Foreign Trade in XIXth Century.

"Full of valuable information, carefully compiled."-Times.

66. Theory and Policy of Labour Protection.

A. L. BOWLEY. 67. History of Rochdale Pioneers. G. J. HOLYOAKE.

Dr. SCHÄFFLE. "Brought down from 1844 to the Rochdale Congress of $1892 . "-\mathrm{Co}-\mathrm{O} p$. News.

68. Rights of Women.

M. OSTRAGORSKI.

"An admirable storehouse of precedents, conveniently arranged."-Daily Chron.

69. Dwellings of the People.

LOCKE WORTHINGTON.

"A valuable contribution to one of the most pressing problems of the day."Daily Chronicle. 


\section{SOCIAL SCIENCE SERIES-(Continued).}

70. Hours, Wages, and Production.

Dr. BRENTANO.

"Characterised by all Professor Brentano"s clearness of style."-Ecommic Reweu.

71. Rise of Modern Democracy

CiI. Burgeaud.

"A very useful little volume, characterised by exact ressarch."-Daily Chronicle.

72. Land Systems of Australasia.

WM. EPPS.

"Exceedingly valuable at the present time of depression and difficulty."Scots. Mag.

73. The Tyranny of Soclalism.

Yves Guyot. Pref. by J. H. L.evy. "M. Gujot is smart, lively, trenchant, and interesting."-Daily Chrunicle.

74. Population and the Social System.

"A very valuable work of an Italian economist." - West. Rev.

75. The Labour Questlon.

"Will be found extremely useful."-Times.

76. Britlsh Freewomen.

77. Sulcide and Insanlty.

78. A History of Tithes.

79. Three Months in a Workshop.

80. Darwinlsm and Race Progress.

81. Local Taxatlon and Finance.

Dr. NiTH.

82. Perils to British Trade.

S3. The Soclal Contract.

S4. Labour upon the Land.

85. Moral Pathology.

86. Parasitism, Organic and Social.

87. Allotments and Small Holdings.

85. Money and Its Relations to Prices.

S9. Sober by Act of Parllament.

90. Workers on their Industries.

91. Revolution and Counter-Revolution.

92 . Over-Production and Crises.

33. Local Government and State Aid.

94. Village Communltles In Indla.

95. Anglo-Amerlcan Trade.

96. A Plain Examination of Sociallsm.

T. G. SPYERS.

C. C. Stoprs.

Dr. J. K. STR.AHAN.

Rev. H. W. CLARKE.

P. GOHRE, with Pref. by Prof. ELY.

Prof. J. B. HaYckaft.

G. H. BIUNDEN.

E. BukGis.

J. J. Rousseau. Editud by H. J. TOzer.

Edited by J. A. HOBSON, M.A.

Arthur E. Gilfs, M.D., B.Sc. MASSART and VANDERVELUR.

J. I. GREEN.

1.. L. Р'кіC:.

F. A. MАСКF. $\angle I E$.

F. IV. G.ALTON.

KARI. MAKX.

K. RODBERTUS.

S. J. CHAPMAN.

B. H. BADEN-POWhLL, M.A., C.I.E.

S. J. CHAPMA.

97. Commerclal Federation \& Colonial Trade Policy. J. DAvinsoN, M.A., I'hil.D.

98. Selectlons from Fourler

99. Public-House Reform.

C. GIDF: and J. FRA.NKI.IN.

100. The Village Problem.

101. Toward the Light.

102. Christlan Soclallsm In England.

103. The Phllosophers and the French Revolution.

104. The History of the Engllsh Corn Laws.

105. The Blology of British Polltics.

106. Rates and Taxes as Affecting Agriculture.

107. A Practical Programme for Working Men.

A. N. Cumming. G. F. MII.LIN.

L. H. BERENS.

A. V. WOOLWORTH.

Prof. P. A. WADIA.

Prof. J. S. Nicholsox, M.A.

ChaRles H. HARVEY.

Prof. J. S. Nicholson, M.A.

EDMOND KELLY.

\section{DOUBLE VOLUMES, 3s. 6 d.}

1. Life of Robert Owen.

LLOYD JONES.

2. The Impossibllity of Social Democracy : a Second Part of " The Quintessence of Socialism". Dr. A. SCHÄFFLE.

3. Condition of the Working Class in England in 1844. FREDiRICK ENGELS.

4. The Principles of Soclal Economy.

5. Social Peace.

6. A Handbook of Sociallsm.

7. Soclalism : its Growth and Outcome.

8. Economic Foundations of Society.

YVES GUYOT.

G. vON SCHCLTZE-GAEVERNITZ.

W. D. P. BLISS.

W. MORRIS and E. B. B.AX.

A. LORIA.

SWAN SONNENSCHEIN \& CO., LIM., LONDON

NEW YORK: CHARLES SCRIBNER'S SONS. 


\section{-}





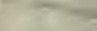




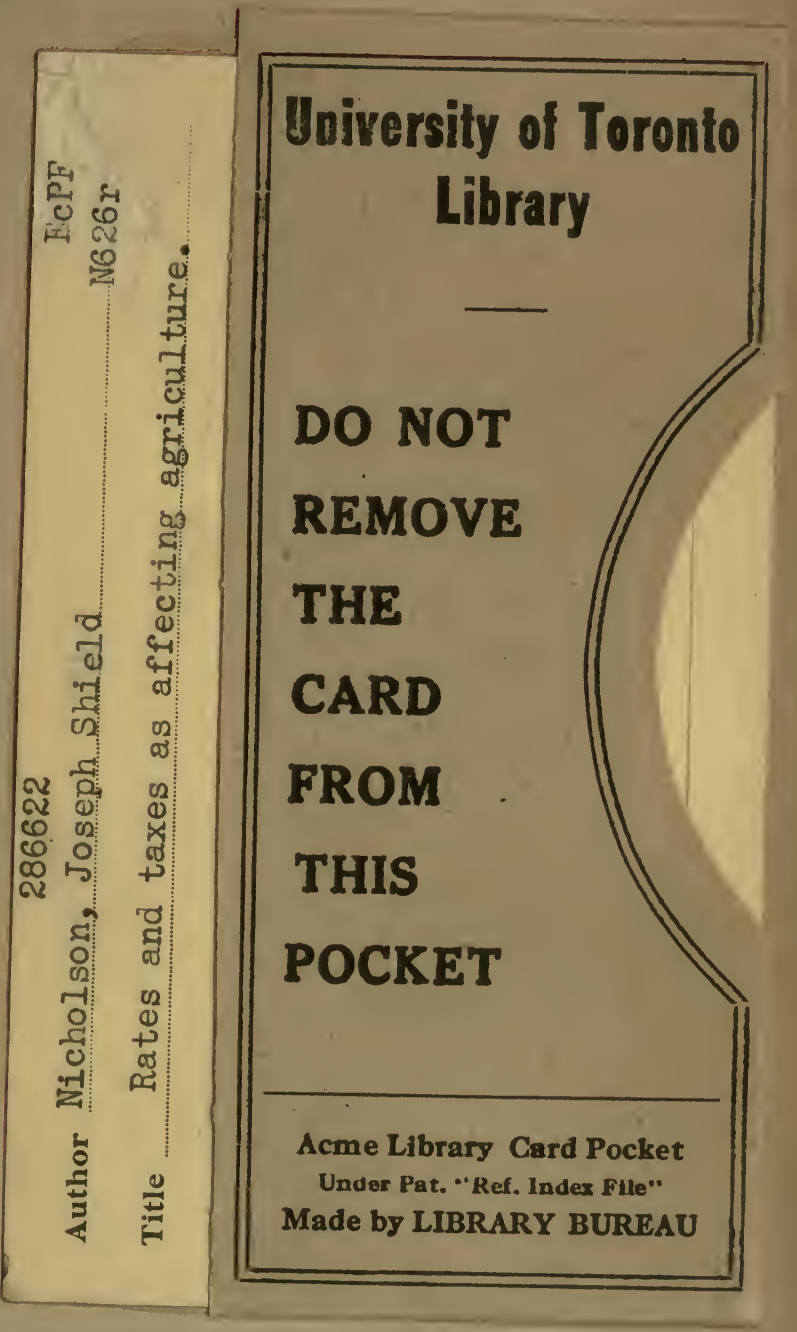


